\title{
FIVE SEASONS OF EXCAVATIONS IN AREAS 2A AND G OF SARUQ AL HADID (DUBAI, UAE): IRON AGE II EVIDENCES OF COPPER PRODUCTION, WORKSHOP AREA AND CEREMONIAL ACTIVITIES
}

\author{
Tatiana Valente (Sanisera Archaeology Institute) \\ Fernando Contreras (Sanisera Archaeology Institute) \\ Ahmed Mahmud(Dubai Municipality - Architectural Heritage \& Antiquities Department) \\ Mansour Boraik Radwan Karim(Dubai Municipality - Architectural Heritage \& Antiquities Department) \\ Mahra Saif Al Mansoori (Dubai Municipality - Architectural Heritage \& Antiquities Department) \\ Hassan Zein (Dubai Municipality - Architectural Heritage \& Antiquities Department)
}

\begin{abstract}
:
Within five years of excavations in Area $2 A$ and $G$ of Saruq al-Hadid, several pit-like structures used in combustion activities were found whose purpose is still unclear. Near these, a rich collection of metal objects from the Iron Age II was gathered, along with evidences of their production at the site. Frequent identification of raw materials and working tools, mainly for jewellery production, suggests that the site was also a production centre for these kind of objects, as well as a site with religious connotation as suggested by the votive objects discovered, such as copper anthropomorphic figurines, snakes, miniature weaponry, and soft stone and ceramic vessels with parallels in other places of worship.
\end{abstract}

\section{KEYWORDS:}

Saruq al-Hadid, Iron Age II, copper production, workshop area, ceremonial activities

\section{RESUMEN:}

Tras efectuar cinco campañas de excavación en las áreas " $2 A$ " y " $G$ " de Saruq al-Hadid, se localizaron más de veinte estructuras de combustión, de las que desconocemos con qué etapa de producción metalúrgica estaban relacionadas. La secuencia estratigráfica se sitúa en la Edad del Hierro II, e integra un conjunto notable de objetos metálicos y de muestras, que evidencian la manipulación del oro y del cobre. Se han documentado, materias primas y herramientas de trabajo para la elaboración de joyas. La distribución espacial de algunos de los objetos, sugieren rituales y ceremonias, con escenificaciones votivas. Buen ejemplo de ello, pueden demostrarlo los hallazgos de figuritas antropomórficas, serpientes y armas en miniatura, recipientes en cerámica y piedra blanda que son habituales y representativos de contextos arqueológicos asociados a espacios sagrados.

\section{PALABRAS CLAVE:}

Saruq al-Hadid, Edad del Hierro II, producción de cobre, área de talleres, actividades ceremoniales

\section{Introduction}

The archaeological site of Saruq al-Hadid is located in the fringes of the Rub al-Khali desert, close to the southern border of the Emirate of Dubai, in the United Arab Emirates. The site itself, extending longitudinally east to west amidst shifting sand dunes, is of difficult interpretation giving the geomorphological conditions upon which it sits. Although three main large areas have been under excavation for years - Areas F and G, Area 2A, and Military Area -, the site seems to extend much further in all cardinal directions. From time to time the sand dunes shift and expose new occupation zones, although these remain to be excavated. 
At first glance a peripheral site, Saruq al-Hadid has shown that it might have been much more than a simple remote place where metallurgical activities took place during the SE Arabian Iron Age ${ }^{1}$.

The slag heaps that cover portions of the site aided in its discovery back in 2001 . Easily visible among the sand dunes, this waste material has helped identify and characterize the site as a metallurgical center whose importance to understand the local metallurgical production was quickly perceived. Although similar slag heaps have been found in the region, particularly in the Hajar Mountains where the metal extraction zones seem to have taken place $^{2}$, there was no apparent justification for the presence of this metallurgical waste in this desert location. In search of answers about why and who produced that metallurgical waste in such a remote location, the site has been excavated by several multidisciplinary teams for almost two decades ${ }^{3}$.

We, the Sanisera Archaeology Institute, which main results are presented in this article, have been researching Saruq al-Hadid since January 2015, however our work could have never been possible without the support, insight and collaboration of Dubai Municipality team, whose excavation efforts have been a constant at the site since its discovery. Is not only on our interpretations, but on Dubai Municipality and every other team that excavated at Saruq al-Hadid, that we were able to reach the results here presented. The extension, material abundance and complexity of the site makes its interpretation difficult to attain but not impossible. With time, continued work and multidisciplinary collaboration we hope to be able to identify the major technologic, economic, social and political features behind the existence of Saruq al-Hadid, but meanwhile, we shall continue contributing with small pieces of interpretation such as the ones we will here present.

Over the course of five excavation seasons (roughly 4 to 6 months each), our team excavated a total of $2.900 \mathrm{~m}^{2}$ in Area $2 \mathrm{~A}$, where stratigraphic deposits ranged between 1 to 2 meters of thickness before reaching the bedrock, and $300 \mathrm{~m}^{2}$ in Area $\mathrm{G}$ where deposits ranged the 4 meters. The excavation was done in extension following the stratigraphic levels that were identified during our first excavation season. Given that the deposits are composed by Aeolic sand dunes, the archaeological stratigraphy often cannot be identified vertically. Instead, for proper identification we had to adapt our methodology to the physical features of the site, being each layer identified by the presence of artefacts whose weight helped stabilized the movement of the dunes upon which they sit. Thus, it was preferable to extend the excavation following the dispersion of the artefacts in situ, recording its height to create a digital stratigraphic record, than through an actual vertical section in the sand dune where only slight changes in sand coloration were observed - which do not correspond to the actual occupations of the site.

Amid these difficult stratigraphic and excavation conditions, the best indicators for the different occupation periods were the objects themselves. As mentioned, they helped stabilize the sand upon which they lay and allowed us to set the theories which we will here debate. The site contains by far the largest collection of copper-base objects - mainly weaponry - ever found in SE Arabia. Adding to these, countless beads of miscellaneous

\footnotetext{
${ }^{1}$ Contreras et al. 2017; Weeks et al. 2017; 2019; Valente et al. 2019.

${ }^{2}$ Weeks 2003.

${ }_{3}^{3}$ Dubai Municipality (Qandil 2005); Jordanian Mission (Al-Khraysheh \& An-Nashef 2007; Nashef 2010); University of Akansas Dubai Desert Survey (Casana et al. 2009; Herrmann et al. 2012); Saruq al-Hadid Archaeological Research Project (Weeks et al. 2017; Weeks et al. 2018; Weeks et al. 2019); Sanisera Archaeology Institute Mission (Contreras et al. 2017; Valente et al. 2019); Thomas Urban and Partner Mission; Polish Centre of Mediterranean Archaeology Mission; Seville University Mission; Tübingen University Mission.
} 
materials were also found everywhere on the site, along with a rich collection of pottery and soft stone vessels. The site also houses the largest collection of seals and gold jewelry of the region, and a yet ambiguous collection of votive objects that includes copper snakes, anthropomorphic figurines and miniature weaponry. The hugely abundant metallurgical waste nonetheless, is the feature that mostly calls our attention, however we couldn't confirm how production was practiced at Saruq al-Hadid yet. No standing structures have been found at the site - aside from a possible one located in Area $\mathrm{G}^{4}$-, several wells, numerous small hearths and post-holes that suggest that some kind of structures existed. Adding to these, the pit-like combustion structures found in Area 2A seems to point to their use in some part of the metallurgical production, but we cannot precise to each part of the process, nor how they were used.

By combining the information gathered, particularly in Area 2A, all points that Saruq al-Hadid was an important center for the production and trade of copper-base objects, gold and miscellaneous bead jewelry, as well as a place where people could meet and perform ceremonial practices, likely associated with the productions being held at the site. The evidences that led to such interpretations will now be discussed in this paper.

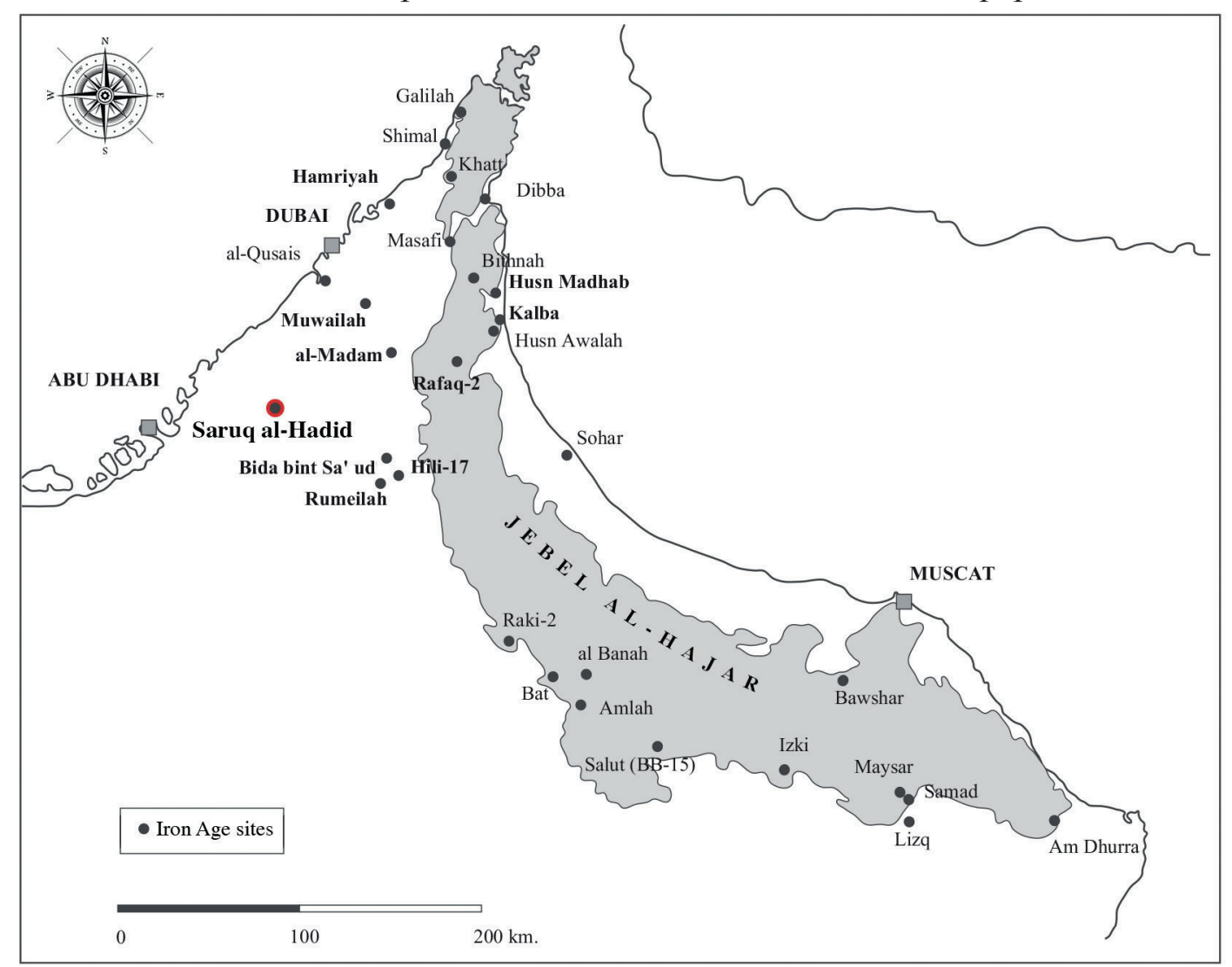

Fig. 1. Saruq al-Hadid location within the SE Arabian Iron Age panorama. (C) Anna Zuber (Sanisera Archaeology Institute).

\section{The periodization of Areas $\mathbf{2 A}$ and $\mathbf{G}$ of Saruq al-Hadid}

Although the stratigraphic sequence of Area $2 \mathrm{~A}$ is timewise narrower than the one in Area $\mathrm{G}$, their timeline interconnects during the period corresponding to the Iron Age II. These periodization sequences have been proved by both relative and absolute dating mainly done

\footnotetext{
${ }^{4}$ Weeks et al. 2019, 1045-1046.
} 
by ours, the SHARP and the DDS team ${ }^{5}$, and we believe these sequences can be expanded and mirrored to other areas of Saruq al-Hadid, as long as material evidence and geomorphological features are considered. It seems that about five millennia ago, aridification processes started to take place that formed the sand dunes which intruded the area ${ }^{6}$, making so that each occupation layer became distributed through horizontal landscapes, who overlapped each other every time a sand dune covered a previous landscape. These landscapes however, are only possible to be identified by the presence of artefacts whose height varies upon the geomorphic and human processes that helped give them shape.

If we identify the Saruq al-Hadid periodization from the lower to the upper layers, we find that all the sand dunes sit upon a cemented gypsum pavement - an inland sabkha - created when the water table reached the surface of these sediments. It seems that these were formed during the Holocene Climatic Optimum (c.7500-4000 BC) ${ }^{7}$, when Indian Ocean Monsoons brought heavy summer rains to the region that sustained lakes and streams, now completely gone. Is upon these first sediments of compacted sands and silts that the older archaeological remains are found. These sediments have been dated by OSL from $5821 \pm 282$ $\mathrm{BP}^{8}$, a progressively more arid period which was believed to have constrained human settlement to coastal, wadi and oasis regions ${ }^{9}$. A belief that needs to be revised after the discovery of desert sites like Saruq al-Hadid and Al-Ashoosh ${ }^{10}$.

The oldest occupational dates found in Saruq al-Hadid come from Area G. At the time of our excavation of this Area four samples were collected to help us date its lower levels and two wells found here ${ }^{11}$. The lower occupational deposit, containing only occasional lithic artefacts, some post-hole negatives and a couple of hearths, was possible to date from $4100 \pm 30$ BP (sample n.68) thanks to a sample collected from one of the hearths that was found below the carving gypsum debris of one of the wells. Immediately over this well carving debris, another hearth was identified and sampled, providing a dating of $3000 \pm 30 \mathrm{BP}$ (sample n.69). This seems to mean that the wells found in Area $G$ were constructed roughly between the Umm an-Nar/Wadi Suq periods, and used approximately until the beginning of the Iron Age I, as suggested by samples (n. 58 and 59) collected from other two hearths found in the sandy deposit of 'Layer 6', which already intrudes the wells and covers them completely.

\begin{tabular}{|c|c|c|c|c|}
\hline Sample ID & Lab Code & Type & ${ }^{14} \mathrm{C}$ age & Calibrated dates \\
\hline n. 58 & Beta- 494290 & Charred material & $2750 \pm 30 \mathrm{BP}$ & $(95.4 \%) 976-822 \mathrm{cal} \mathrm{BC}$ \\
\hline n. 59 & Beta-494291 & Organic sediment & $2880 \pm 30 \mathrm{BP}$ & $\begin{array}{c}(88.8 \%) 1131-973 \mathrm{cal} \mathrm{BC} \\
(2.4 \%) 958-939 \mathrm{cal} \mathrm{BC} \\
(2.2 \%) 1161-1144 \mathrm{cal} \mathrm{BC} \\
(2.0 \%) 1192-1176 \mathrm{cal} \mathrm{BC}\end{array}$ \\
\hline n. 68 & Beta-494292 & Organic sediment & $4100 \pm 30 \mathrm{BP}$ & 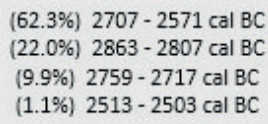 \\
\hline n. 69 & Beta-494293 & Organic sediment & $3000 \pm 30 \mathrm{BP}$ & $\begin{array}{c}(89.4 \%) 1304-1126 \text { cal BC } \\
(6.0 \%) 1377-1348 \text { cal BC }\end{array}$ \\
\hline
\end{tabular}

Fig. 2. Summary table of AMS analysis done in four samples collected in the lower levels of Area $G$ (2018).

\footnotetext{
${ }^{5}$ Contreras et al. 2017; Weeks et al. 2019; Herrmann, Casana \& Qandil 2012.

${ }^{6}$ Parker et al. 2006.

${ }^{7}$ Casana, Herrmann \& Qandil 2009.

${ }^{8}$ Herrmann, Casana \& Qandil 2012.

${ }^{9}$ Potts 2001.

${ }^{10}$ Contreras et al. 2016; Casana, Herrmann \& Qandil 2009.

${ }^{11}$ The sample analyses was carried out at the Beta Analytic Radiocarbon Dating Laboratory, and the calibration was calculated using INTCAL13 Database.
} 
When compared to the published dating results from the SHARP team, we can identify that the date obtained from sample n.68 is slightly older than their oldest one collected, but it still matches the chronologies for them proposed for the "Horizon V"12. Similar hearths had been dated before which also provided a $3^{\text {rd }}$ millennium chronology ${ }^{13}$, and collected ceramic sherds of sandy red ware from the Umm an-Nar period ${ }^{14}$ confirms the presence of the site's inhabitants, who lived of the natural resources of the area. At this time the area was possibly still free of sand dunes, which provided a quite flattish surface, but traces of aridification becomes visible by the presence of plant casts that compose the sediments from our lower levels - up to 'Layer 6', and also identified by the SHARP team in their corresponding "Horizon V"15. It seems that vegetation flourished among these rising sand dunes for a time, at least until the Iron Age II, where the presence of plant casts cease to be identified in this Central Area of Saruq al-Hadid.

It was also during this time, more precisely during the Wadi Suq period, that the "bone layer" - as is commonly known, was formed. Named as "Horizon IV" and intensively studied by the SHARP team, this deposit seems to have been formed by the continued discarding and accumulation into a mound of animal bones, over a millennium. It was a large bonerich midden which included chipped and groundstone artefacts, marine shells, occasional copper-base artefacts and pottery sherds consistent with those of the Wadi Suq and Iron Age I period $^{16}$. The area southwest of this mound which we excavated in 2018 was already out of its limits, but deposits matching such periods were found by the presence of the excavated wells (7 and 8), which seem to have been carved and in use at this time, as referred above, and by the presence of hearths and coarse handmade ware similar to that one described as Fabric $\mathrm{C}$ by the SHARP team ${ }^{17}$. Considering stratigraphic elevations, it seems that at this time the area was still quite flattish, with only the central mound progressively raising as more and more animal bones were accumulated.

The sandy deposit identified as 'Layer 6' which filled the wells excavated, as referred, dated from the early Iron Age II period by the absolute dates obtained from the hearths found, but also by a relative dating from a snake decorated incense burner found ${ }^{18}$. As also referred, abundant remains of plant casts are still present in this deposit, but the surface of this layer already raised $70 \mathrm{~cm}$ above the previous deposit, which in turn was only $30 \mathrm{~cm}$ above the bedrock floor. Furthermore, above 'Layer 6', Iron Age II deposits started to overlap progressively higher and higher upon each other. Is perceptible that from the Iron Age II onwards the sand dunes start to accumulate rapidly - at least in this Area -, perhaps more intensively by the existence of the "bone layer" which might have helped accumulate here all the sand blown from south and west, and by the inexistence of a vegetation cover that could stabilize the sand dunes. During the Iron Age II, this Central Area greatly contrasts with Area $2 \mathrm{~A}$ which seems to remain free of any major accumulation of sand dunes, as we shall describe ahead.

Considering the all information provided so far about the lower levels of the site, the question that comes to mind is why settle, at least temporarily, in this location? Four important evidences about the site come to mind. First of all, it seems the site has been part

\footnotetext{
${ }^{12}$ Weeks et al. 2019: 1059-1060.

${ }^{13}$ Herrmann, Casana \& Qandil 2012: 58.

${ }^{14}$ Weeks et al. 2019: 1060-1061.

${ }^{15}$ Weeks et al. 2019: 1044.

${ }^{16}$ Weeks et al. 2019: 1044-1046; 1060-1061.

${ }^{17}$ Weeks et al. 2019: Fig. $11(\mathrm{a} / \mathrm{b}) ; 1061 ; 1073$.

${ }^{18}$ Benoist 2010a: 17-18.
} 
of a "hunting corridor" used since the SE Arabian Bronze Age as suggested by the bone mound found at Saruq al-Hadid and by the discovery of other desert sites like Al-Ashoosh ${ }^{19}$. Secondly, it appears that this whole area was still empty of the present sand dunes, or at least this was an inter-dune area where people could live and perform their activities protected from the major wind currents. Is important to remember that often inter-dune areas appear in this region exposing large areas of the sabkha, as these Aeolic sand dunes shift their position. Thirdly, it seems the area was not as arid as it is today. Hydrologically speaking, the site sits on the eastern hydrological zone of the Hajar Mountains where a still high water table is hidden by the sand dunes ${ }^{20}$. The presence of several wells discovered in Area G, not deeper than 250 centimeters, might support the presence of a high water table at the time, though yet to confirm. Lastly, the presence of plant casts in the lower levels of Area G seems to represent a period where flora could grow in sand deposits who seem to have started accumulating, or shifting to the area during the Wadi Suq period, but while still low, the presence of vegetation may have helped stabilize these low sand dunes, preventing them from abrupt shifts as often occurs today. The combination of all these factors seems thus to point towards a suitable habitat where both food, water and fuel sources were located.

It seems valid to suggest that the presence of food, water and fuel allowed for the development of Saruq al-Hadid into a habitable place since the Bronze Age, however, is harder to explain why it was chosen to be a center for copper-base objects production during the Iron Age II, since the nearest sources of the metal are approximately $100 \mathrm{~km}$ away in the Hajar Mountains. The reasons for it currently transcends the archaeological evidence, but nonetheless let us approach what chronological evidences are indicative of such period.

Area $2 \mathrm{~A}$ seems to be the place where the metallurgical activity occurred, or at least part of it as we will discuss further ahead in this paper. We still can't precise how this activity was performed, but the presence of several pits carved into the sabkha containing the remains of some kind of combustion activity, and within the same archaeological levels and in proximity to copper prills, scrap and unfinished objects, seems to suggest it. This is the lower occupation level identified immediately above the sabkha floor of Area 2A, which both suggests that this area wasn't occupied during the Bronze Age as Area G was, nor that it had any accumulated sand by the time these structures were in use. This may either be because the area was simply never used before, or because it was cleared from any sand and previous occupation, although this last suggestion seems unlikely, as people seemed to simply occupy open inter-dune zones or perform their activities over flattish dune zones, if it didn't affect what they were doing, as we saw in the layers identified above.

From the charcoal samples collected from the interior of these pits we could date most of them from between 1000 to $800 \mathrm{BC}$, with one which chronology extends from the 1200 to $1000 \mathrm{BC}$ and another from the eighth to the sixth centuries $\mathrm{BC}^{21}$. Adding to the absolute chronologies provided by the charcoal in the pits, were abundant fragments of ceramic and soft stone sherds that are similar to examples found in other Iron Age II assemblages of

\footnotetext{
${ }^{19}$ Weeks et al. 2017; Weeks et al 2019; Casana, Herrmann \& Qandil 2009; Contreras et al 2016.

${ }^{20}$ In the Environmental Atlas of Abu Dhabi Emirate, "Inland sabkhas form where the water table lies very close to the surface. Near surface evaporation concentrates salts until a halite (salt) crust develops. Lateral growth of this crust causes cracking and uplifting to form halite polygons with uplifted margins. (...)The shallow water table, coupled with poor drainage, results in rainfall pooling at the surface to produce ephemeral ponds. As these dry, microbial mats akin to those seen in the coastal sabkhas develop, sediments exposed through quarrying and wind erosion record cyclic changes in climate over thousands of years. The presence of dune sands indicates dry periods while sabkha formations indicate wetter periods or periods with higher water tables." (https://www. environmentalatlas.ae/geographicInheritance/dunesAndSabkha).

${ }^{21}$ Contreras et al. 2017, 59
} 
the region ${ }^{22}$. These mainly include ceramic examples of sandy buff, common red wares and grey ware, but also of several bowls, cups, boxes and lids decorated with a wide diversity of linear geometric patterns consistent with Iron Age examples. However, although most of the vessels found in this lower level were found in what seems to be their original place and mostly whole, is important to refer that many were fragments of vessels who after shattering scattered through the area not only horizontally but also vertically in the stratigraphy. This may be due to the movement of the sand dunes or by the actions of animal or human activities that happened afterwards, but what matters is the fact that in the deposit immediately above, the exact same type of vessels, from the same chronological period, are found. The same happens to the copper-based objects identified in both lower layers, all representative of the same type of weaponry and jewelry ${ }^{23}$, paralleled with Iron Age examples of the region.

From the evidences obtained, all seems to point that both layers (4 and 3 of Area 2A) correspond to the Iron Age II. Although we do not have absolute dates for the second-last deposit, if we compare the material found in "Layers 4 and 3" of Area 2A to that one found in "Horizons III and II" of Area G ${ }^{24}$, we can see that they match material-wise. They both include a similar variety of copper objects and gold jewelry, as well copper ingots and prills that could be used in the copper production held at the site, pottery and soft stone vessels corresponding to the Iron Age II, and the distinctive presence of votive copper snakes. Furthermore, both "Horizons III and II" from Area G were dated from the early Iron Age $\mathrm{II}^{25}$ as "Layer 4" in Area 2A was. The major visible differences are only in the type of ceramic vessels used in both Areas, whose shapes identified in Area 2A correspond to painted spouted vessels, grey ware jars and slipped sandy buff bowls, while in Area $G$ it mainly comprises pedestalled bowls and large vessels often decorated with snake appliqués, and Area 2A clearly evidence a wider variety of working tools such as gabbro stones and copper tools such as tweezers, spoons, pins/awls, needles, etc. that could had been used in metallurgical production, not to mention the larger amount of copper prills and scrap metal, which Area G doesn't contain. So, although material content and object distribution in "Layer 3" points towards the presence of a ceremonial/ritualized occupation, similar to that one found in "Horizons III and II", is possible that any "rituals" performed in Area 2A, had a slightly different connotation from those ones performed in Area G. We believe is also relevant to point out that no incense burners nor iron swords were ever found in Area 2A, while during our excavation of Area $\mathrm{G}$, these objects were preponderant in "Layers 3, 5 and 7", whose distribution between sterile deposits, much resembled the described "Horizon II" of the SHARP team" ${ }^{26}$.

Furthermore, a prevailing question about Area 2A remains that could help us understand the purpose of such "ceremonial/ritualized" deposits. Was there any relationship between the combustion pits of "Layer 4" and the deposits of "Layer 3" in Area 2A? This secondlast deposit extends throughout Area 2A, and is where most of the artefacts are found. The identification of objects such as copper weaponry, particularly arrowheads, are a constant in this deposit, and they all sit in a sandy layer that intruded Area 2A and completely covered the combustion pits found here, however they tend to concentrate in zones without pits underneath. The objects are found scattered without any reasonable order, except for arrowhead bundles and bead jewelry that at times are found carefully placed as if "offerings" of some kind. Associated to these are also fragments of the referred soft stone and ceramic

\footnotetext{
${ }^{22}$ Potts 1997; Benoist 1999; Benoist \& Ali Hassan 2010; Benoist \& Méry 2012; Fritz 2009; Ziolkowski 2001.

${ }^{23}$ Taha 2009; Potts 1992: 383-387.

${ }^{24}$ Weeks et al. 2019: 1046-1047; 1062-1065.

${ }^{25}$ Weeks et al. 2019: 1062-1065.

${ }^{26}$ Weeks et al. 2019: 1046-1047.
} 
vessels, whose shapes are comparable to those encountered in Iron Age meeting places, and notably in collective buildings such as the columned halls of Masafi-1 or the building II of Muweilah $^{27}$. Is the association, disposition and artefacts parallelism that lead us to believe that perhaps this occupation layer reflects the occurrence of some kind of celebrations, or perhaps rituals performed after/during the metal production activity, and associated to a deity represented by a snake ${ }^{28}$ - a constant symbol present in this deposit in the shape of miniature copper snakes.

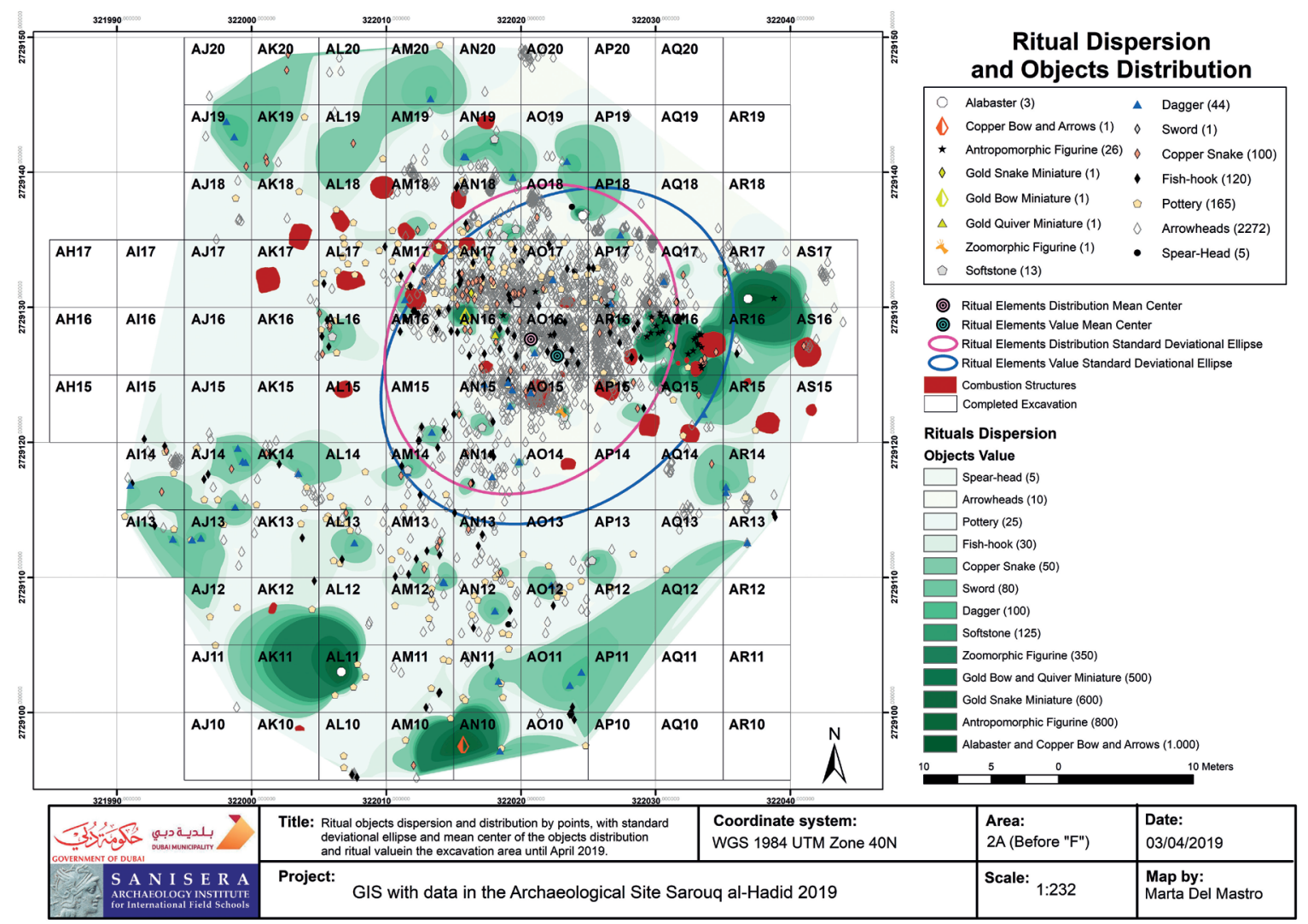

Fig. 3. Artefacts concentrated in Layer 3 and on the surface of Layer 4 in Area 2A. The map was modelled to represent both artefacts distribution and "votive" impact dependent upon its function. Objects that without an utilitarian function have a higher "votive" impact-represented in darker green -, such as copper bows, copper snakes, anthropomorphic figurines and miniature weaponry, while the ones with an utilitarian character where represented in lighter green, such as copper weaponry, vessels and copper fish-hooks. (C) Marta Del Mastro (Sanisera Archaeology Institute).

Nevertheless as referred, the characteristics of this deposit are somewhat similar to the ones found by our team in Area G, in the deposits we named 'Layer 3', 'Layer 5' and 'Layer 7' - even though perhaps representing slightly different "ceremonial" connotations. Those deposits include Iron Age II materials such as copper arrowheads and vessels, snake decorated ceramics, and soft stone vessels decorated with typical patterns of the period ${ }^{29}$. However, as referred, the most preponderant finds were three iron swords found in 'Layer 3 'and four incense burners - one of copper in "Layer 3", one of copper and another of ceramic

\footnotetext{
${ }^{27}$ Benoist et al. 2012a; Magee 2007.

${ }^{28}$ Benoist et al. 2012b: 299.

${ }^{29}$ Potts 1992: 383-387; Benoist 1999; Potts 2012: 96.
} 
in "Layer 5", and another of ceramic in "Layer 7". The incense burners in particular have been associated with cultic places such as Bithnah- $44^{30}$. All these objects were agglomerated in thin lenses, as if representing deliberate depositions in precise moments, separated by periodic intervals where sand accumulated; thick abandonment deposits (approximately $50 \mathrm{~cm}$ thick) without archaeological intrusions were found in between these "deposition" lenses ('Layers 4 and 6'). Thus, stratigraphically, these 'ceremonial' deposits are also slightly different from 'Layer 3' in Area 2A where artefacts accumulated over each other in a single deposit of approximately $30 \mathrm{~cm}$, and as if uninterruptedly where the objects concentrate.

Above these "ceremonial/celebration/ritualized" deposits, in both Areas there is what we generically denominate 'Layer 2'. This is a large abandonment deposit that seems to extend throughout Saruq al-Hadid, found below 'Layer 1' or the 'Slag Layer'. It appears to have been formed by the natural movement of the sand dunes, which was later trapped and consolidated by the weight of the slag in the above deposit. Is often sterile from archaeological materials although some occasionally intrude from 'Layer 1 '.

The famous 'Slag Layer' which allowed the site to be found almost two decades ago, is concentrated in large mounds composed by this metallurgical waste. A large mound extended between areas $\mathrm{G}$ and $\mathrm{F}$, but as the excavation expands, it seems that this deposit is being found progressively lower and lower upon the landscape, and the slag is becoming less frequent. In our excavation of Area 2A, we practically extinguished the mound, as it was mainly concentrated in the northeast portion of the Area. Dating to this mound was done by our team in Area 2A from charcoal material found within the deposit, which provided a chronology between the $15^{\text {th }}-16^{\text {th }}$ centuries $\mathrm{AD}$, and matches the discovery of twelve pottery vessels that also date from the Middle Islamic period. These include examples of Buraimi cooking ware and Julfar common ware, unglazed wares with white surface, and also examples of monochrome turquoise alkaline glazed wares and a possible Bahla glazed ware ${ }^{31}$. However, some of these wares - with a chronology spanning to earlier periods -, may also match the dating done at the 'slag layer' of Area G by the SHARP team, which provided a chronology from the $9^{\text {th }}$ century $\mathrm{BC}$ until the $10^{\text {th }}$ century $\mathrm{AD}^{32}$.

This large chronological frame obviously hinders the interpretation of Saruq al-Hadid's metallurgical activity, not to mention the fact that all this metallurgical waste is dissociated from any production structures, including the pits found in Area 2A, if proved that they were used for the production of copper-base objects.

\section{Evidences for copper metallurgical production at Saruq al-Hadid}

\subsection{The slag}

The metallurgical waste that was found covering the Areas F, G and $2 \mathrm{~A}$, on what is commonly called "Slag Layer", is not associated with any metallurgical structure visible, and is distributed in the shape of large mounds (see fig. 5) that spread through the Areas by the actions of deflation and the shifting of the sand dunes. While excavating these deposits, is common to identify "pockets" of denser accumulation of slag, which suggest that this waste was being discarded in the same spots forming small mounds. However, by continuous dumping of this material over a large period of time, it end up covering a large portion of the Areas forming two main large mounds (one in Areas F and G, and another in Area 2A). Furthermore, although this material is concentrated only in the above "Layers 1 and 2" of the site, we have to consider that it might have started being dumped here still during the

\footnotetext{
${ }^{30}$ Benoist et al. 2012 b.

${ }^{31}$ Kennet 2002.

${ }^{32}$ Weeks et al. 2019: 1066-1068.
} 


\section{Layers 1-4 and bedrock 3D Perspective view}

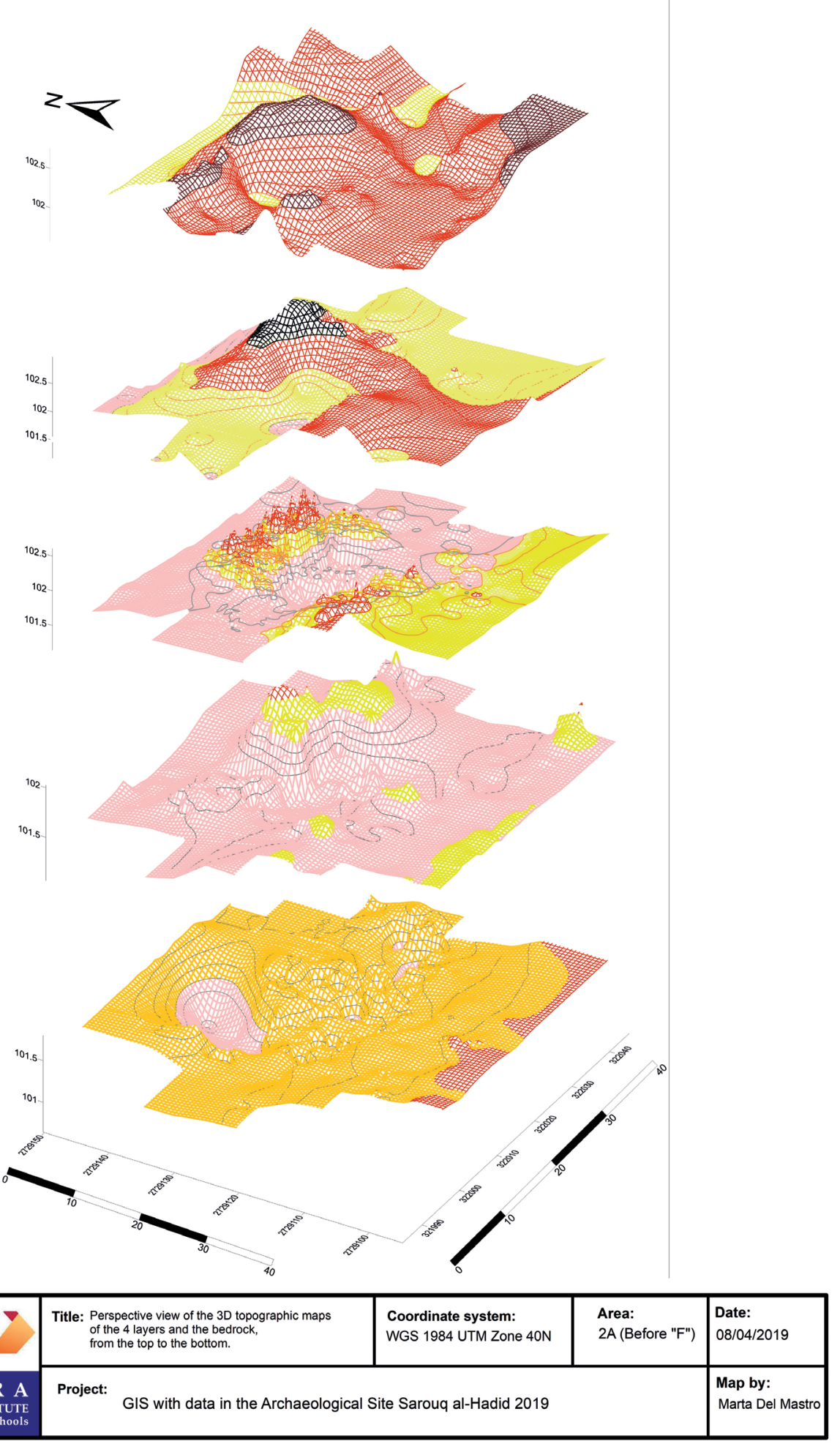

Fig. 4. Topographic perspective of Area 2A, from Layer 1 (top) to the bedrock floor (bottom). (C) Marta Del Mastro (Sanisera Archaeology Institute). 
Iron Age II - particularly considering the chronologies obtained in the "Horizon I" done by the SHARP team. However, is hard to understand how it all agglomerated at the top of the stratigraphic sequence, above all the deposits that contained Iron Age II materials identified in situ, unless all of it was produced later in time when the site was possibly swept to locate metal artefacts that could be reused/melted into new ones, and copper prills that could be further smelted to extract the desired metal. Is also important to remember that in the lower levels of Area 2A, associated to the combustion pits, only copper prills (apparently still rich in iron, sulfur and gangue ${ }^{33}$ ) are found. In "Layer 4" there are no traces of the "skimmed" slag that is common in 'Layer 1'.

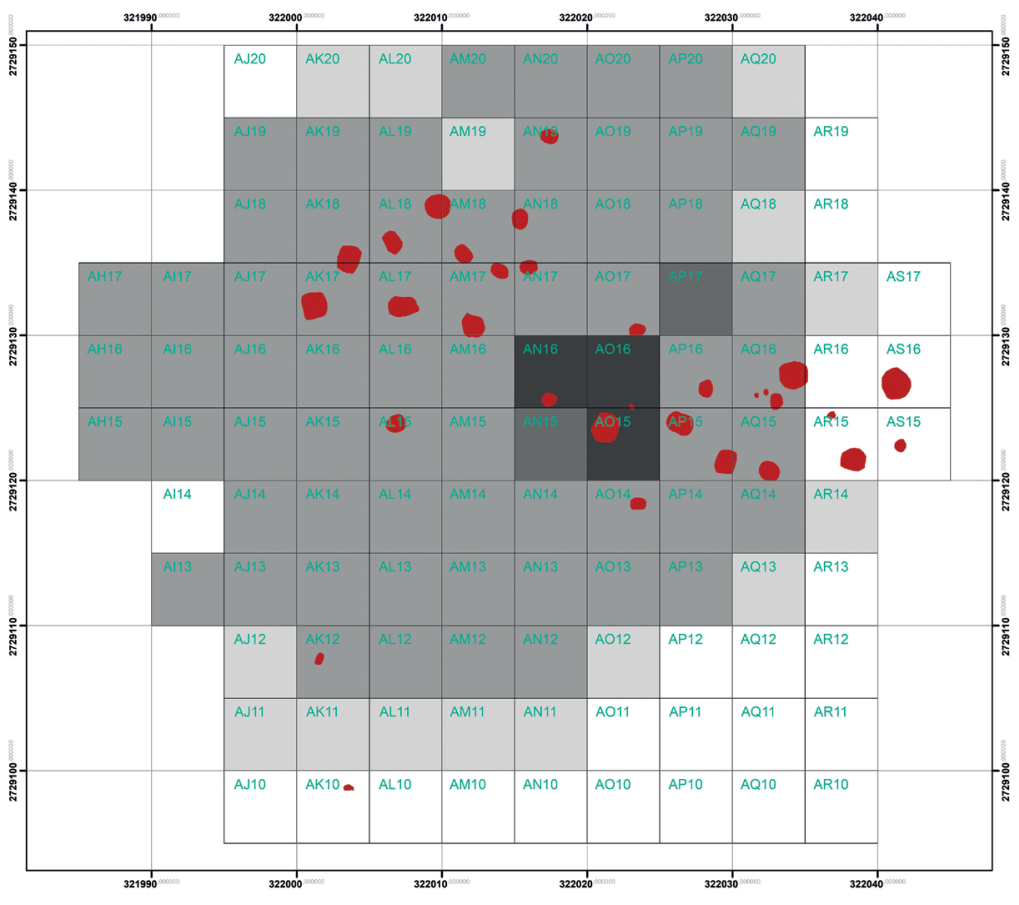

Slag Distribution by squares of Layers 1 and 2 Islamic Period

\section{Combustion Structures} $\square$ Completed Excavation Density Weight (gr)

$11,000000-1000,000000$

$1000,000001-100000,000000$

$100000,000001-150000,000000$

$150000,000001-314703,000000$
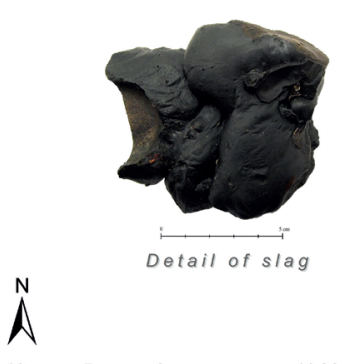

Detail of slag

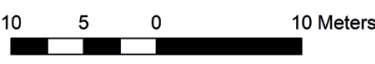

\begin{tabular}{|c|c|c|c|c|}
\hline 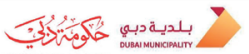 & $\begin{array}{l}\text { Title: Density distribution map of the slag by squares } \\
\text { of the layers } 1 \text { and } 2\end{array}$ & $\begin{array}{l}\text { Coordinate system: } \\
\text { WGS } 1984 \text { UTM Zone 40N }\end{array}$ & $\begin{array}{l}\text { Area: } \\
\text { 2A (Before "F") }\end{array}$ & \begin{tabular}{|l|} 
Date: \\
11/03/2019
\end{tabular} \\
\hline 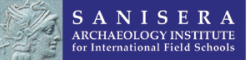 & \multicolumn{2}{|c|}{ Project: GIS with data in the Archaeological Site Sarouq al-Hadid 2019} & Scale: ${ }_{1: 250}$ & $\begin{array}{l}\text { Map by: } \\
\text { Marta Del Mastro }\end{array}$ \\
\hline
\end{tabular}

Fig. 5. Distribution of slag in Layer 1 and 2 in Area 2A. There is a clear epicentre in squares AN15, AN16, AO15 and AO16, which seems to be where this waste was being discarded.

(C) Marta Del Mastro (Sanisera Archaeology Institute).

Furthermore, aiding on the suggestion that 'Layer 1' was formed by the dumping of discarded materials, and perhaps by the swept for copper products to melt and smelt, is the frequent inclusion of fragmented materials such as pottery and soft stone vessels (from the Iron Age II period) $)^{34}$, broken pieces of copper and iron objects, innumerous miscellaneous beads (including gold ones) which are impossible to be seen if the sand is not sieved through, and occasional gold and copper wires. All these fragments appear randomly discarded among the slag without any apparent care, clearly as if simply dumped away. On the other hand, such image of randomness is never observed in the lower deposits of the site. In those ones,

\footnotetext{
${ }^{33}$ This assumption is only being made by its appearance. Thorough analysis to this material and the one located in "Layer 1" is pending financial support.

${ }^{34}$ Vessels found in 'Layer 3', but particularly 'Layer 4' of Area 2A, and in 'Layer 3, 5, and 7' of Area G, tend to be find whole or just crushed by the weight of the above layers.
} 


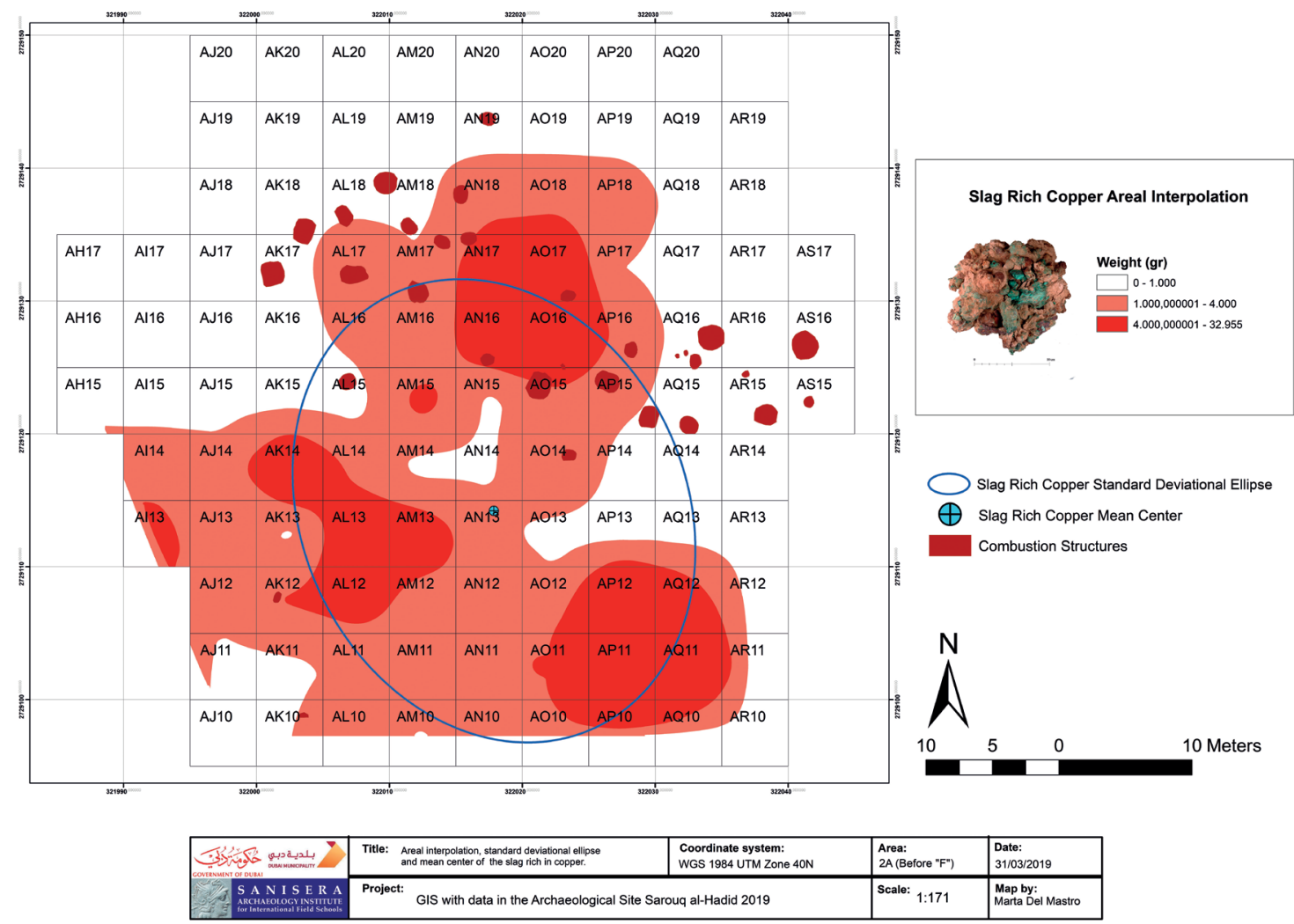

Fig. 6. Distribution of copper prills in Layer 4 in Area 2A. Larger concentrations tend to be outside the locations of the combustion pits, although is common to find it within the whole southern "workshop" area, and on the surface of the combustion debris from these pits, that tend to be thrown out around them. (C) Marta Del Mastro (Sanisera Archaeology Institute).

the finds normally present physical integrity and are distributed in an orderly manner, even if sometimes geomorphological conditions may make it appear otherwise at first glance. There are clear agglomeration zones for objects that are finished or to be finished products, others that agglomerate objects that have deformities or are broken and were probably placed together for being melted into new objects, and there are visible agglomerations of copper prills, as if ready to be used. Of notice is a small mound of copper prills found distributed among four squares in the southeast corner of Area 2A (AP11, AP12, AQ11, AQ12) and other small agglomerations adjacent to combustion pits.

Considering all the data referred, melting and smelting activities clearly seem to have happened at Saruq al-Hadid. Supporting this idea is not only the objects, "skimmed" slag and prills found, but also the occasional inclusions of clay furnace walls with slag still attached, found both within the copper prills of 'Layer 4' in Area 2A, and in 'Layer 1' or both Areas $2 \mathrm{~A}$ and $\mathrm{G}$. Is possible that these smelting furnaces were used throughout the whole smelting history of the site, and installed directly on the sand, which led to their complete disintegration and scattering through the area, since they have to be destroyed to remove the desired smelted metal ${ }^{35}$. Nonetheless, it remains difficult to trace how all these activities interacted and progressed in the copper production line at Saruq al-Hadid. Stratigraphic deflation and apparent disturbance of the Iron Age deposits in recent periods makes our interpretations difficult and tricky.

\footnotetext{
${ }^{35}$ Weeks et al. 2017: 44-45.
} 


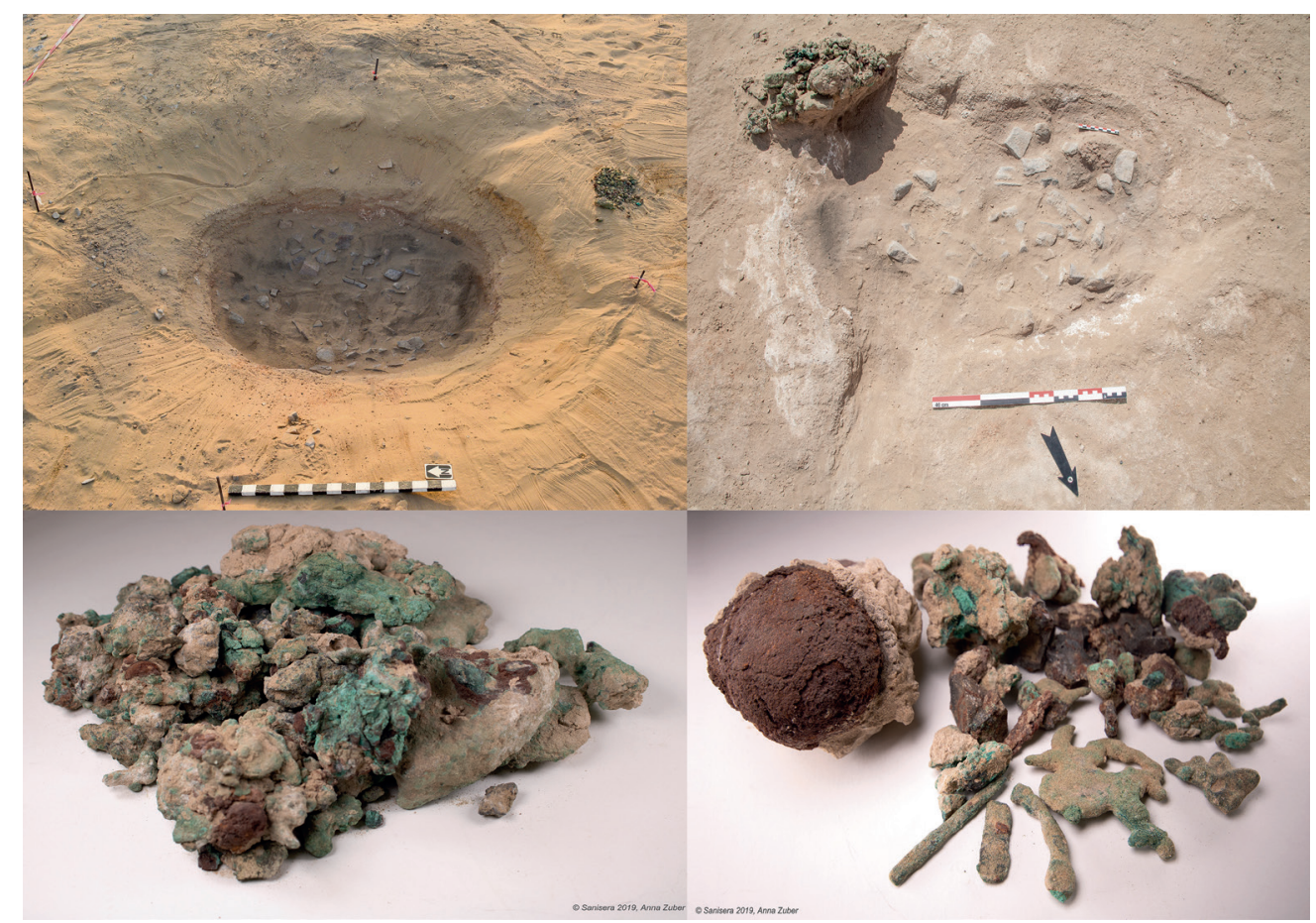

Fig. 7. Aside from copper prills and ingots scattered randomly through "Layer 4" of Area $2 A$, there were two agglomerations of such materials positioned next to two of the combustion structures found. (C) Anna Zuber (Sanisera Archaeology Institute).

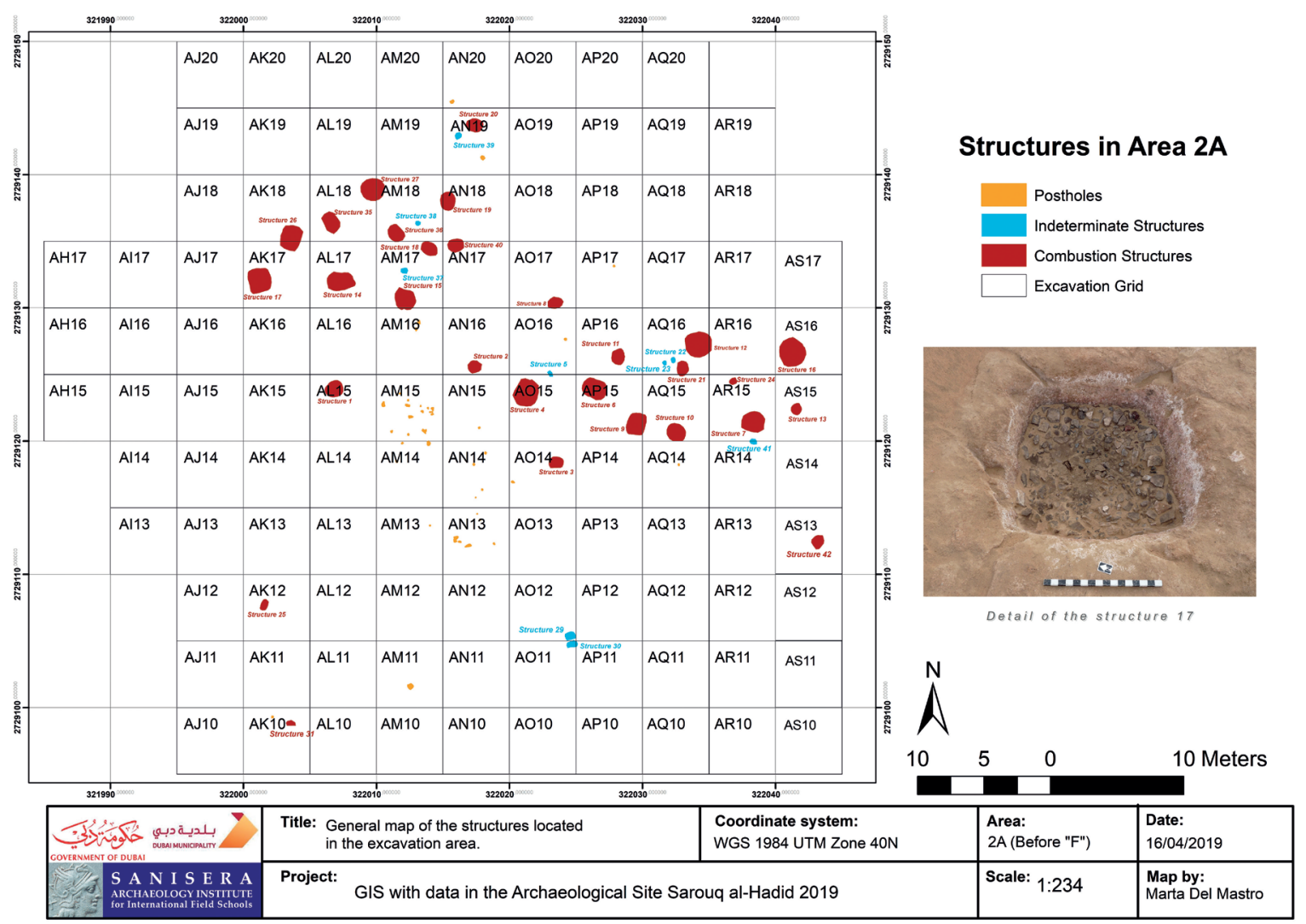

Fig. 8. Distribution of combustion pits, unidentified structures and post-holes in Area 2A. (C) Marta Del Mastro (Sanisera Archaeology Institute). 


\subsection{The pits}

The combustion pits found in Area 2A seem to be directly associated with the copper metallurgical production held during the Iron Age II, given the contexts into which they were found and the chronologies they provided. The problem is to understand how and for what they were used for. A total of 29 pits were so far found and excavated, being 10 of them dated from the Iron Age II period as referred, and most of them within a timeframe from 1000 to $800 \mathrm{BC}$. They are mainly concentrated in the northern excavated portion of Area 2A, and we know by the presence of charcoal deposits identified in northern section of the excavated limits, that more are located further north, and possibly also east (see fig. 8). All the pits have a rather oval or rounded shape, between 100 to $200 \mathrm{~cm}$ in diameter - although in average they have $160 \mathrm{~cm}-$, and between 50 to $70 \mathrm{~cm}$ in depth. Exception to these values are the rounded pits 13 and 24 with only $50 \mathrm{~cm}$ diameter and 30/40 $\mathrm{cm}$ in depth, and the oval pits 25 and 31 with 120 and $90 \mathrm{~cm}$ length, and 35 and $15 \mathrm{~cm}$ in depth, respectively.

From the excavation of these pits, we also identified that they all contained exactly the same composition within. Approximately 30 centimeters of charcoal and burned sandstone slabs are always found at the bottom of pits, which clearly suggests that they were used for some kind of activity that demanded the combustion of something ${ }^{36}$. While the charcoal was used to feed the fire, the purpose of the sandstone slabs (ranging from 10-20 cm in size) was likely to maintain the heat inside the pits. Both materials for this combustion could be collected nearby. Sandstone outcrops can be found just one kilometer west of Area 2A, and more exist nearby. The charcoal, probably produced from plant material, was probably also obtained at the site, as the lower levels of Area G seem to suggest by the abundant presence of plant casts; the area may have contained a vegetation cover that was harvested until its exhaustion. Although today the site only presents a few remaining ghâf trees, is possible that during the pre-historic periods these and other species populated the area. Further archaeobotanic studies should be consider to prove this theory.

Furthermore, these charcoal and sandstones deposits are not only limited to the interior of the pits. Surrounding every pit there is always an abundant quantity of this combustion debris that appears separated by intervals of fragmented gypsum and thin lenses of sand. This seems to presuppose that these pits where at times cleaned from the debris in its interior, which is indiscriminately thrown out to its immediate surroundings, and while doing it so, part of the walls slightly crumbled, thus creating intervals between each cleaning action. The lenses of sand on the other hand, suggest that some time was allowed to pass until the next cleaning. The exact time is unfortunately impossible to precise. Observing today's sand movements we could say that it could easily accumulate in just a day of wind, unfortunately we cannot say this was the case during the Iron Age, as the variables for it are just too many and unclear. Nonetheless, the important fact about this observation is that the slightly different sizes of pits might be justified by the amount of cleaning actions that they might have been submitted. This may also have been the cause for the abandonment of a pit and construction of a new one. If a pit became too large to maintain the necessary heat requirements, for example, it was discarded and a new one was built. However, to prove such hypothesis more comparative studies, chronological dating, and perhaps experimental archaeology, would need to be done. So far, from the 10 pits dated, there was no direct relationship between size and chronology, nor between distribution and chronology. All we can say is that the pits weren't all used at the same time, as confirmed by the dating obtained, and by the fact the some were covered by the debris of adjacent ones, which presupposes that the covered ones were already in disuse. The

\footnotetext{
${ }^{36}$ The analysed samples from these deposits that were used to date the pits were identified as charred or organic material, likely plant/wood material that we still have to identify exactly which.
} 
reasons for its disuse, and even for how far a new one was carved, seems so far quite random. No direct relationship between size, shape or location seems to exist.

Random was also the way the combustion debris was disposed outside the pits. It seems that it didn't bother those ones using the pits to have all that debris surrounding them, nor even the fragmented gypsum from the pits initial carving. Next to each pit, we always found below its combustion debris, the fragmented gypsum from its carving that "fused" together, forming a compacted mass of approximately 10 centimeters in thickness, dispersed around the pit. Sometimes this compacted plaque of gypsum was found above the debris of a nearby pit, suggesting us the nearby pit was older than the one from which the gypsum corresponded. Thus, it seems the all the charcoal and sandstone pollution didn't affected the production of whatever was being made in those pits, however inside of them, thorough and regular cleanings had to be done. The last combustion activity performed inside each pit is the one they didn't bother to clean because the structure would be disused, and which now we find still in place.

Is important to refer here that pits 13 and 24, much smaller than any of the pits referred, although containing the exact same combustion debris inside, might have been used for another purpose. Their smaller size might suggest us that, as well as is the case of pits 25 and 31 - quite shallow and far from all the other ones. However, there is also no indication for what they might have been used for. No single artefact was ever found inside the structure that could help us understand their purpose ${ }^{37}$. The only material evidence we could find in direct association with these pits is the occasional discovery of copper prills agglomerations (see fig. 7), as well as the frequent presence of copper tweezers, spoons and scrap metal.

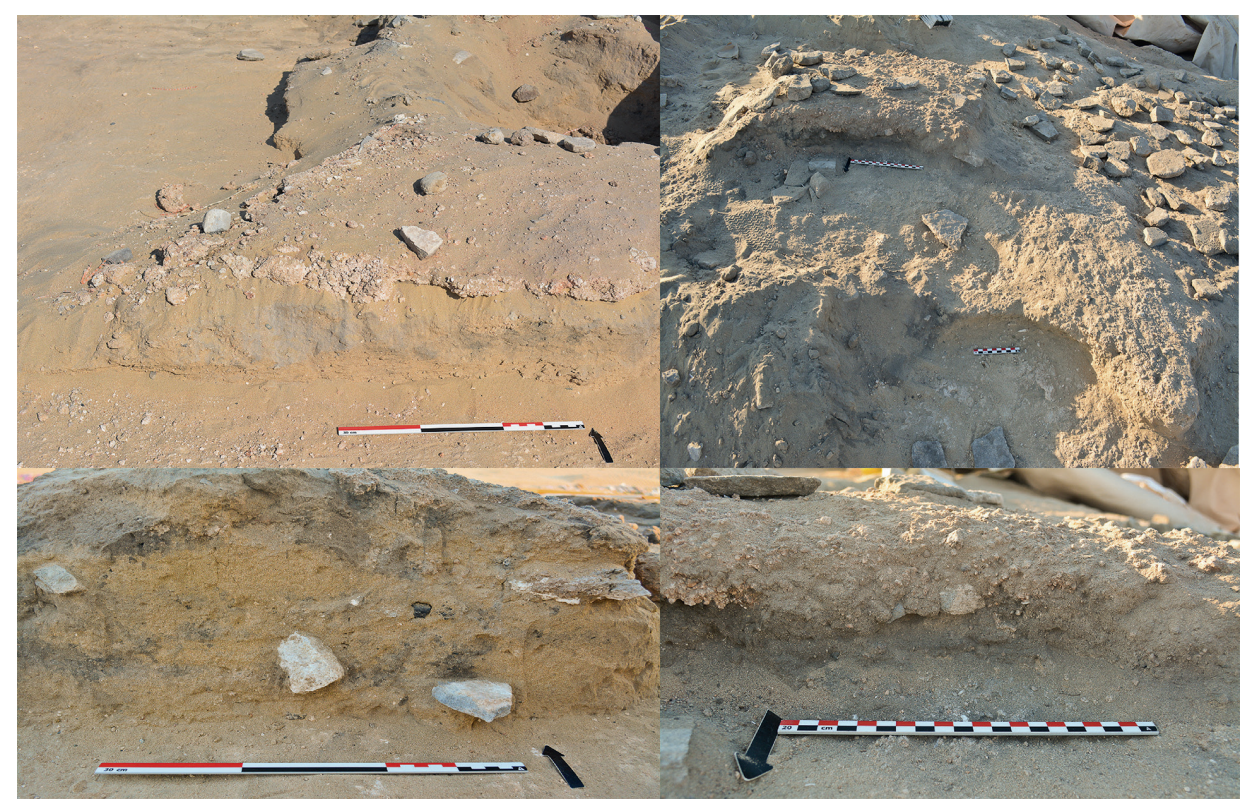

Fig. 9. Intertwined layers of sand, charcoal and sandstone debris from the combustion activities, and fragmented gypsum are the common stratigraphic compositions that surround the combustion pits. Every time a pit is cleaned, its debris is thrown away in its surroundings. The compacted plaque of fragmented gypsum from the pits carving is also always found in its surrounding, sometimes immediately above the bedrock floor, or above debris from the combustion activity, if older pits are located nearby. Sand often intrudes in between these carving or combustion activities.

(C) Tatiana Valente (Sanisera Archaeology Institute).

\footnotetext{
${ }^{37}$ Trace elements analysis is planned, pending the required funding, in order to identify any elements that might suggest what was being made inside these pits, and perhaps help us to understand how these structures were used.
} 
Finally, we would also like to refer the presence of several round/oval depressions in the gypsum floor of Area 2A, many within the overall dispersion zone of the pits. These are quite shallow depressions, no further than $15 \mathrm{~cm}$ deep and quite small, 30 to $40 \mathrm{~cm}$ in diameter. Unfortunately again, there was nothing that could point towards what they might have been used for. They didn't contained anything within, aside from the expected 'Layer 4' deposit that intruded them, and that could be composed of "clean" sand, or charcoal if located close to a combustion pit. Throughout the whole Area 2A, several post-holes were also identified, many concentrated south of the pits zone, suggesting that some perishable structures existed here. Nonetheless, no evidence of how they might have looked like or for what would they have provided shelter for exist.

Considering everything that was mentioned, although more research is obviously required in Area 2A, we can fairly suggest that the combustion pits found here are greatly similar to the ones found in As-Safah ${ }^{38}$, in Oman. They exhibit roughly the same size, shape, and contain the same stratigraphic composition. Nevertheless, it seems that three types of combustion pits were identified. Two of the types are quite similar, matching the ones in Area 2A of Saruq al-Hadid, although one type is considerably larger than the other, exhibiting diameters of over 2 meters. These were interpreted as charcoal production pits, while the smaller ones were referred to as furnaces for the recast of disused objects. This seems a valid suggestion, although in Saruq al-Hadid, as referred, the structures do not vary much in size, and the charcoal production may have been located in the Military Area where a large charcoal-rich mound was discovered ${ }^{39}$. The third type of combustion pit from As-Safah, although not exactly as the smaller pits referred to in Area 2A, presents similarities in terms of size and stratigraphic content. These are referred to as forging pits, where objects could be finished, and were associated to stone tools that could have been used as sharpening tools, hammers and anvils. In fact, the southern portion of Area 2A, where the small combustion pits 25 and 31 were found, also contained such type of materials.

\section{Area 2A: a workshop place}

The more the excavation of Saruq al-Hadid enlarges, the more it seems that during the Iron Age the site was divided into several zones where distinct activities were performed. It all points that Areas F and G were used for the "ceremonial/ritualized" deposition of objects (mainly of iron and copper-based weaponry and miscellaneous jewelry, accompanied by incense burners and vessels whose content we could not precise); Area 2A was mainly a workspace where copper-base objects and perhaps bead jewelry was being produced, although "ceremonial/ritualized" deposition of objects seem to have happened as well; and the zone commonly named the Military Area, seems to have been where charcoal was being produced, likely for the metallurgical activity. Furthermore, from reports provided by Dubai Municipality, it seems that several archaeological zones exist towards north, east and west of the referred Areas, where numerous Iron Age artefacts were also found. Is very likely that other activity/habitat zones can be found in these referred Areas, making the site far from finished or completely understood. In those Areas key elements may lie which could help us understand the site, thus is important to consider them for the future research of the site.

\footnotetext{
${ }^{38}$ Genchi, Giardino \& Castelluccia 2013.

${ }^{39}$ As per personal communication from the Dubai Municipality team which is excavating this Area, a stratigraphic sequence composed of almost 4 metres of charcoal layers was found, which also included innumerous fireplaces. The real extension of the mound has not yet been identified. Final interpretations and publication about this Area are still in preparation.
} 
Nevertheless, returning to what has been excavated and to what we know, particularly regarding Area 2A, it seems acceptable to designate the area as the "workshop" of Saruq al-Hadid. As mentioned, the pits carved into the gypsum floor, although not completely understood, seem to have been related somehow to the production of copper-based objects. The abundance of copper prills also seems to suggest that these were being accumulated in the Area for further smelting, and the product of that smelting turned into the innumerous copper-based objects found at the site. The fact that the copper prills found at Saruq al-Hadid would have to be further smelted in order to extract all the impurities they still contain seems relevant. However, how this smelting was done remains unclear. Could the combustion pits found in area 2A have been used for such? Genchi, Giardino \& Castelluccia ${ }^{40}$ in their report of As-Safah, refer that no ores where ever found, as neither in Saruq al-Hadid. They suggest that the copper prills and ingots were brought with a first smelting done to the site, then further smelted was done there to remove impurities, and only then transformed into the objects. They refer this would be the most obvious process considering the low frequency of slag at the site, however Saruq al-Hadid has plenty of slag, the only problem is that is located above all Iron Age II stratigraphic deposits. Nevertheless, the SHARP team was able to identify charcoal material from within some of the slag of "Layer 1", which was dated from the Iron Age $\mathrm{II}^{41}$. Pertinent to refer about these evidences, is also the discovery of a spouted jar in the southern portion of area $2 \mathrm{~A}$, which contained inside a concretion of copper prills and scrap (see fig. 10). The context into which was found, and the fact that spouted vessels are the most numerous vessels found in both Saruq al-Hadid and As-Safah ${ }^{42}$, seems relevant and should be further discussed.
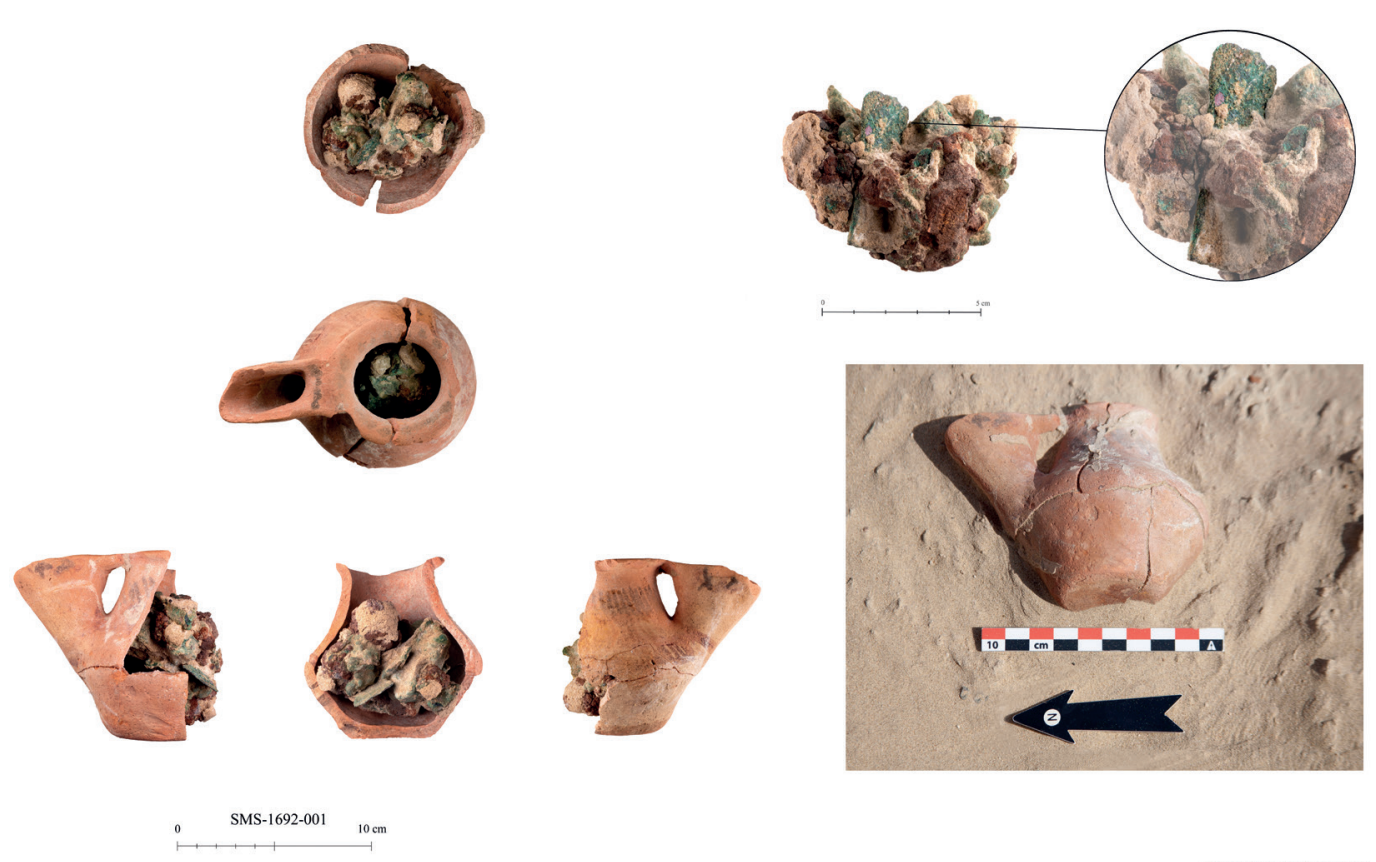

Fig. 10. Spouted vessel found in the southern portion of Area 2A, in Layer 4, contained a concretion of copper prills and scrap in its interior. (C) Anna Zuber (Sanisera Archaeology Institute).

\footnotetext{
${ }^{40}$ Genchi, Giardino \& Castelluccia 2013: 56-57.

${ }^{41}$ Weeks et al. 2019: 1066-1068.

${ }^{42}$ Genchi, Giardino \& Castelluccia 2013: 16.
} 
Particularly in the southern portion of Area 2A, several objects were as well found unfinished, while others presented severe damages or malformations. These were often found agglomerated as pending being melted into new objects. Several copper wires/strips were also found here which could be transformed into several of the discovered objects such as the copper spoons, bracelets, rings, and scale plates. The innumerous copper-based weaponry found at the site, on the other hand, seems to have been shaped with use of molds, given their milimetric similarity. Is possible that they have been produced using sand molds easily available at the site, for obvious reasons -, although evidences for such technique have not been found yet ${ }^{43}$. Nevertheless, such production hypothesis have also been suggested at the site of As-Safah ${ }^{44}$, where unfinished casted axe-heads were found, and hammering is suggested by the discovery of hammer-stones and the "Type 3" furnaces, which seem to have been used to heat the copper objects for hammering processes.

Aside from the copper-based objects, there are also evidences suggesting Area 2A might have been the place where hundreds of gold beads were being produced, as well as innumerous other beads of miscellaneous materials ${ }^{45}$. Despite a thorough study on over 5000 miscellaneous beads found in Area 2A is pending to confirm our theories, the gold beads have already been the subject of a study, who not only suggested how these beads were produced, but that it was quite plausible that they were being produced on site ${ }^{46}$. The discovery of several gold filaments and ingots seems to confirm this theory, and the copper spoons and tweezers found in Area 2A could have been used to shape these beads. Is also important to refer that the gold beads, spoons and tweezers were often discovered near the combustion pits, on the surface of the charcoal debris deposits mentioned previously.
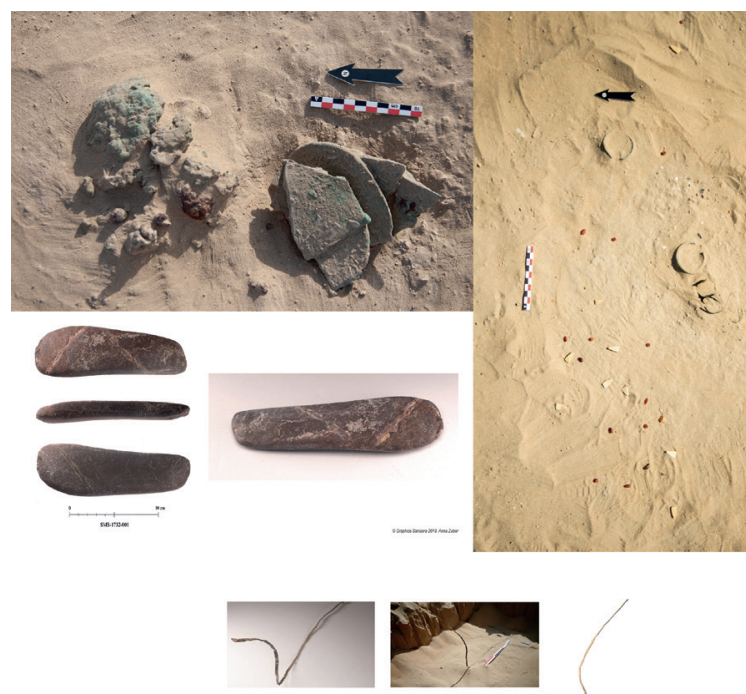

Fig. 11. In the southern portion of Area $2 A$, there was a frequency of copper scrap, which included broken objects, copper wires and bars. Copper prills agglomerations were also frequent, as well as gabbro stones that may have been used as working surfaces or tools. (C) Anna Zuber (Sanisera Archaeology Institute).

\footnotetext{
${ }^{43}$ A typological study on the copper-based objects found at Saruq al-Hadid is currently under development that we hope will provide further insights on these objects production techniques and contextualization within SE Arabia, as well as be a source of reference, given that Saruq al-Hadid comprises the largest collection of such materials in the region. Analysis to the composition of such objects and comparison with the copper prills found at Saruq al-Hadid and to other metallurgical references of the region is intended, however this research is pending financial support.

${ }^{44}$ Genchi, Giardino \& Castelluccia 2013: 54-55.

${ }^{45}$ Weeks et al. 2017: 53.

${ }^{46}$ Soriano et al. 2018.
} 
Finally, given that both copper-based and gold objects seem to have been produced at the site, and that innumerous iron fragments were also found throughout the whole Area $2 \mathrm{~A}$, as well as present as iron swords in the "ceremonial/ritualized" deposits of Area G, we can ask if iron objects were also being produced here. Again in As-Safah, the presence of iron objects, led the authors to suggest that these were being forged in the same furnaces that were used to melt the copper. They refer that in ancient Europe iron bloom used to be traded into the production center, and there transformed into objects ${ }^{47}$. Could this have been the case at Saruq al-Hadid? From our experience at Area 2A and G, iron was only found in the shape of fragmented or complete objects. However the SHARP team identified several pieces that could be classified as ingots ${ }^{48}$. "These included fragments whose morphology and shape suggested unfinished manufacturing (e.g. partially manufactured sword blades); possible 'complete' objects of very basic shapes (oval, rectangular, etc.); and sword hilts or doubleedged pieces whose non-fractured appearance suggested that they could have been used as constituents of composite blades". Unfortunately, mainly because of iron poor preservation and lack of forging structures and residues, it remains uncertain if these fragments could in fact be semi-finished products or be used in secondary production activities.

\section{Saruq al-Hadid: a trading centre}

Provided all the evidences that makes of Saruq al-Hadid a metallurgic centre, and considering its extensive collection of metal finds, it seems reasonable to believe that it might have been an important trading centre for SE Arabian society. Substantiating this idea is the presence of several scale plates and stamp seals that were found in Area 2A also, but in others Areas of the site as well. Furthermore, these might indicate that the entire operatory chain (from raw materials to finished products) was being controlled, likely for economic purposes, but for political reasons also.

In Area 2A alone, six plate scales and thirteen stamp seals were found, either in Layer 3 or 4. In our excavation of Area G we didn't found any of these, but Dubai Municipality found few dozens of such items during their two decades of excavations of the Areas $\mathrm{F}$ and G. The scale plates could have been used as tools to weight the innumerous materials brought in and out of the site, probably to better control every activity from the acquisition to the transformation of such materials, and their subsequent trading as already transformed objects (weaponry and jewellery). Obviously, all of this is mere speculation mirrored on common knowledge obtained from our own understanding of the world, however, the 53 seals found at Saruq al-Hadid alone ${ }^{49}$, has to mean that a clear administrative control was being set upon these goods. Although to date no sealings have ever been found in the SE Arabian Iron Age, this doesn't mean that these were simple amulets, as has been suggested ${ }^{50}$, particularly when so many are found at a site like Saruq al-Hadid. The fact that they might have originated in regions outside SE Arabia (in Mesopotamia, Elam, Dilmun, Egypt and the Levant) however, must be further researched in order to understand the real purpose of such objects ${ }^{51}$.

Although our knowledge about the economic, social and political organization of metal production in SE Arabia is very limited ${ }^{52}$, continued studies - particularly focusing on sites such as Saruq al-Hadid -, may in time help shed some lights on the subject. Despite the

\footnotetext{
${ }^{47}$ Genchi, Giardino \& Castelluccia 2013: 59.

${ }^{48}$ Weeks et al. 2017: 46-51.

${ }^{49}$ Karim 2017.

${ }^{50}$ Potts 2012: 98.

${ }^{51}$ Karim 2017.

${ }^{52}$ Weeks 2003: 51-53.
} 
absence of standing structures at Saruq al-Hadid, its rich artefactual collection should be further researched and compared with other sites of the region, as we believe it may further our knowledge into the social, economic and political relationships of SE Arabia entities. It has already been referred that the ceramic assemblage from Saruq al-Hadid, shows similarities with those found in gathering/meeting/ceremonial places, such as the columned halls. It has been proposed that these buildings were used by the elites, showing a combination of features that included decorated bridge-spouted vessels, large storage jars - often including snake appliqué decorations, the use of incense attested by the presence of incense burners, and the presence of stamp seals. Using P. Magee ${ }^{53}$ words "The combination of elite banqueting equipment and objects that may have been used in a religious context within these columned buildings provides evidence for increasing social and economic differentiation, the likes of which are not previously attested for southeasten Arabia."

Nevertheless, whatever the reasons for such social and economic differentiation, the appearance of specialized sites like Saruq al-Hadid denotes an intensification in the search of metal products. It also seems reasonable to believe that people wouldn't had free access to copper products, thus their production must have been controlled somehow, perhaps by different entities/polities that would be responsible for the different stages of the process, individually or simultaneously. Furthermore, if we consider that the amount of material collected reflects only the one left on site for being unfinished or because it was a votive offering, the real amount of objects produced must have been exponentially greater. Saruq al-Hadid geographical location, far from all known Iron Age settlements, though centred between these sites and accessible by all, may mean that several entities from these sites could attend such production centres and perform the desired exchanges. Obviously for now, this is mere speculation. Much more about Saruq al-Hadid needs to be assessed, but we are confident that with further research some of these paradigms can be proven.
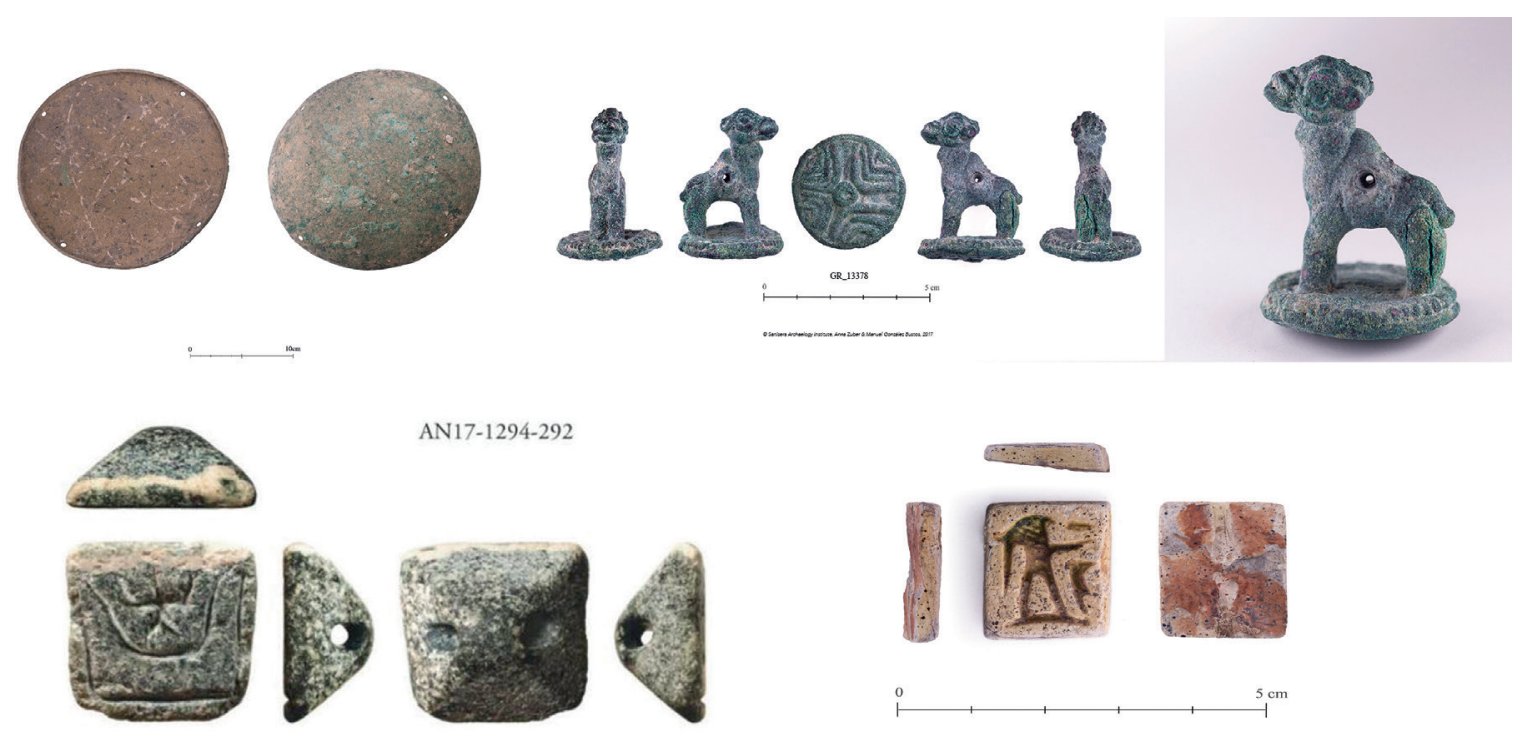

Fig. 12. Several scale plates, of different sizes, were found at Saruq al-Hadid, as well as numerous seals, apparently from different provenances. (C) Anna Zuber \& Manuel González (Sanisera Archaeology Institute).

\footnotetext{
${ }^{53}$ Magee 2007: 90-91.
} 


\section{Saruq al-Hadid: a place for meeting, celebrations and rituals}

Difficult to assess and understand in SE Arabian Iron Age is also the "snake cult". Numerous sites have reported the presence of snake decorative motives in ceramic, but also in the shape of small copper snakes whose functionality can only be votive ${ }^{54}$. Generally they do not appear in burial nor domestic sites, but they abound in sites associated to cultic and communal/gathering practices ${ }^{55}$. In Saruq al-Hadid alone, a total of 100 copper snakes, 1 miniature gold snake and 13 pottery sherds decorated with snake appliques were found in Area 2A (in Layers 3 and 4), while one copper snake and 2 sherds decorated with snake appliqués were found on our excavation of Area G (within Layer 1). Although there seems to be a preponderance of such symbolic elements in Area 2A, other teams make notice of their presence in Areas F and G as well ${ }^{56}$.

The presence of such items at a site like Saruq al-Hadid seems to confirm that the site was not only a metallurgical centre, but also a place of cult and gathering. In fact, its prominent metallurgical features seem to presuppose the existence of a "snake cult". Several publications make reference to the "snake" being a symbol of vigour and fertility, the guardian of groundwater, provider of wealth, power, vitality and immortality, and related to the arts of fire and mining ${ }^{57}$. It is not uncommon to find copper droplets or ingots associated to votive copper snakes, ceramic decorated with snake representations, and even miniature weaponry, in places such as Bithnah-44, Masifi-1, Masafi-3, building G of Rumeilah and building II at Muwailah ${ }^{58}$. All these were connoted as cultic places where meetings and celebrations could have been performed as well. Although Saruq al-Hadid did not revealed any standing structures similar to the ones referred, it presented a very similar collection of finds.

Concentrated near three of the referred pits carved into the gypsum floor of area $2 \mathrm{~A}$ (pits 8,11 and 12), were also 23 copper anthropomorphic figurines which were found lying on the surface of these structures charcoal debris. Dispersed randomly with these figurines were several copper snakes, miniature copper axe-heads and some small copper discs or plates whose purpose is still unclear ${ }^{59}$. All these artefacts seem to lack a functional purpose, but they might have been important votive objects, whose meaning transcends the information obtained from the archaeological record.

Adding to the referred votive objects, is important not to forget the hundreds of objects found in Layer 3 of Area 2A which includes randomly scattered, but also bundles of copper arrowheads, daggers, axe-heads, fish-hooks, needles, pins/awls and tweezers. Numerous gold beads, and what appear to be nose-rings, are also a constant in this deposit, as well as countless beads scattered all around, but sometimes found giving shape to proper necklaces. All this seems to mean that despite the reasons for "depositing" such objects here, they were fulfilling some kind of purpose that transcends us. There is no reason to believe that such objects were simply abandoned. All they required considerable resources and technical skills to produce them, and social, political and economic cooperation - although not clearly understood yet -, was likely mandatory for their production at Saruq al-Hadid. Thus, these objects probably fulfilled a "sacrificial" process that was required to thank a deity - likely figured by the snake, protector of fire and metalwork - for allowing them to produce such items. Is also possible that these "sacrificial" ceremonies were celebrated by all of those who participated in the referred productions, and perhaps accompanied by banquets, exchange of goods, and celebration of social and political contracts ${ }^{60}$, all which required an artefactual assemblage as the one encountered.

\footnotetext{
${ }^{54}$ Potts 1991; Taha 2009; Benoist 2010b; Benoist et al. 2012b; Boucharlat \& Lombard 1985.

${ }^{55}$ Benoist 2010a.

${ }^{56}$ Weeks et al 2019: 1070.

${ }^{57}$ Mouton, Benoist \& Cordoba 2011; Benoist et al. 2012b: 299-300; Benoist et al. 2015.

${ }^{58}$ Benoist et al. 2015: 26-33; Boucharlat \& Lombard 1985; Magee 1998.

${ }^{59}$ Valente, T. et al. 2019.

${ }^{60}$ Benoist 2010a: 138-139.
} 

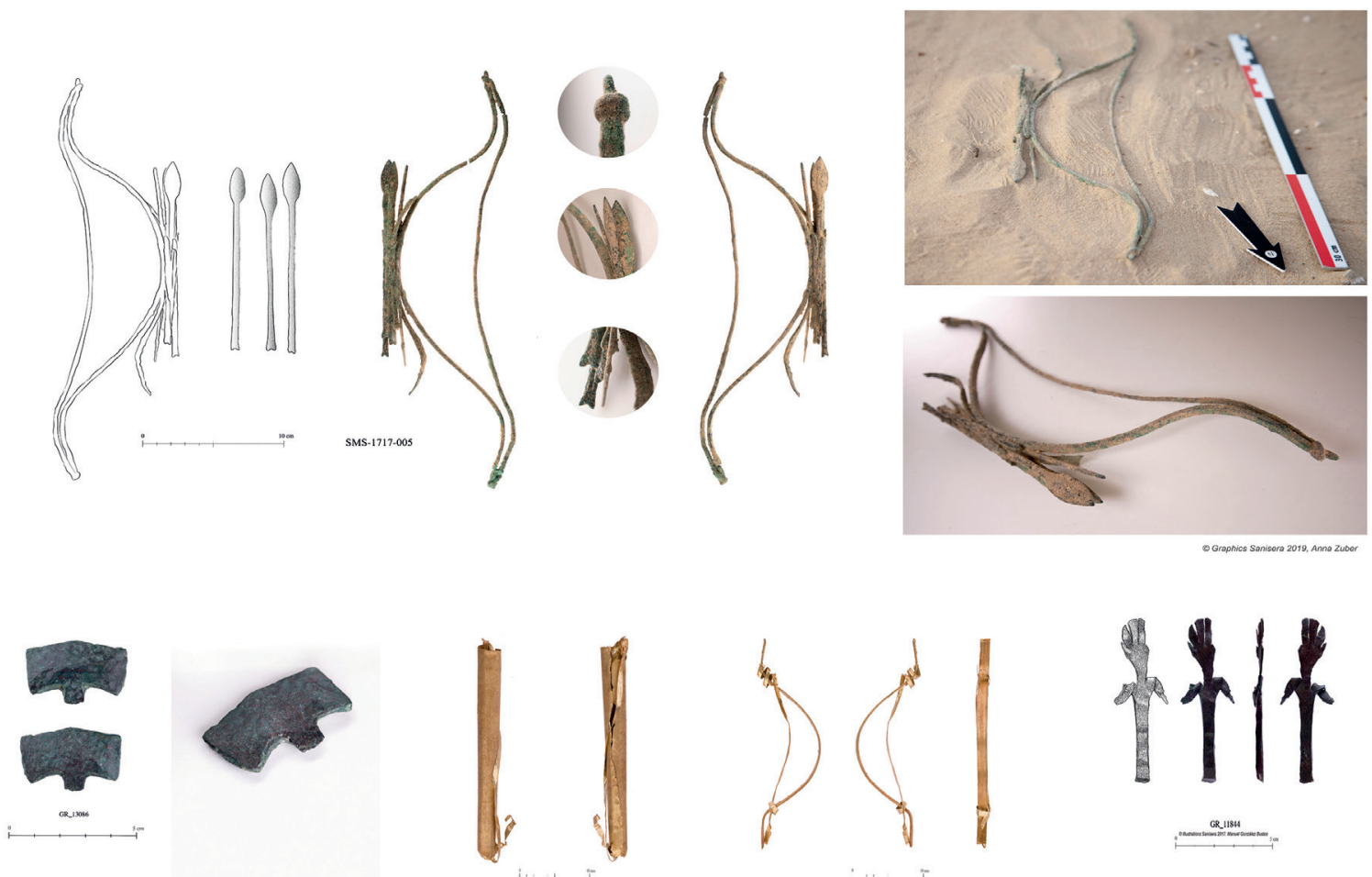

Fig. 13. Several votive objects have been discovered in Area 2A of Saruq al-Hadid like copper anthropomorphic figurines and copper and gold miniature weaponry. (C) Anna Zuber \& Manuel González (Sanisera Archaeology Institute).
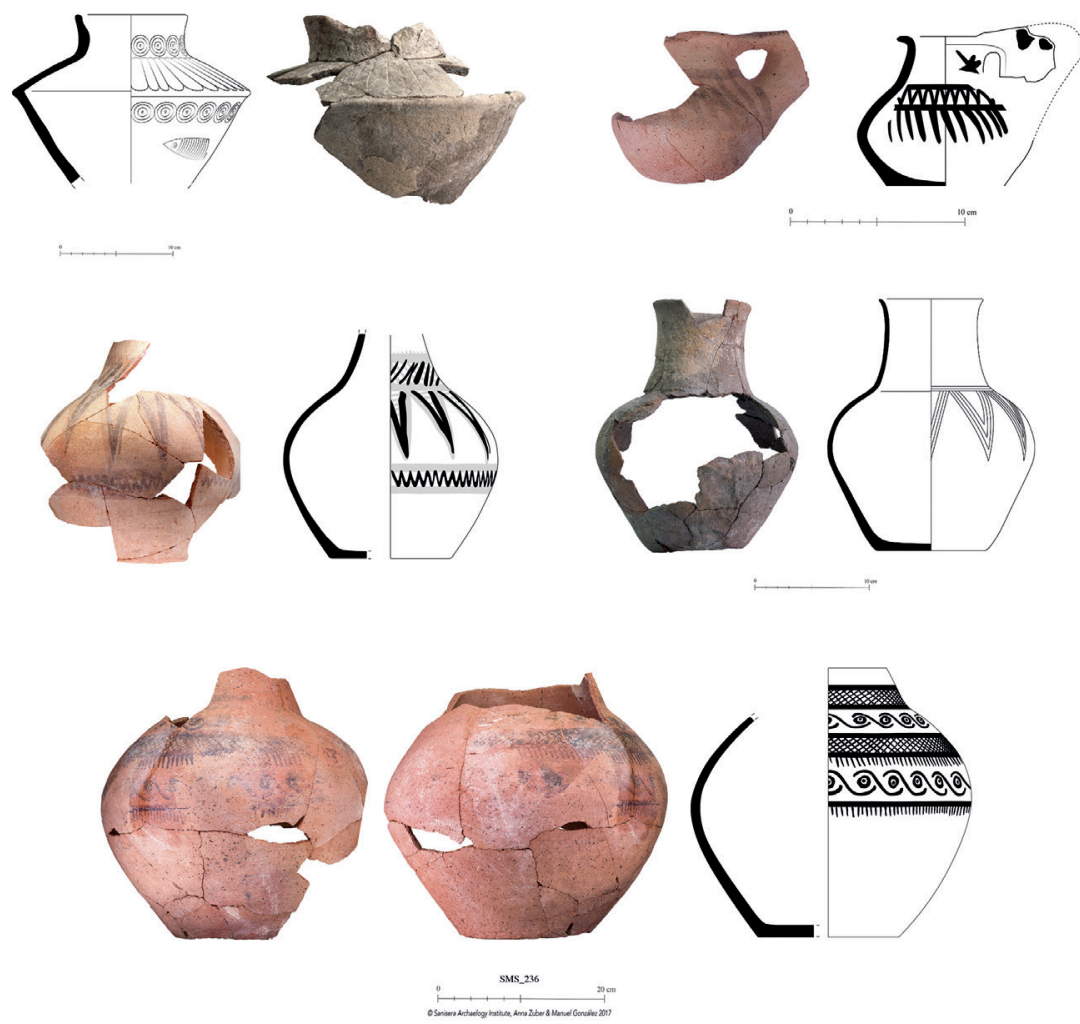

Fig. 14. Spouted vessels and jars of painted ware and grey are the most common shapes found in Area 2 A of Saruq al-Hadid. (C) Anna Zuber \& Manuel González (Sanisera Archaeology Institute). 

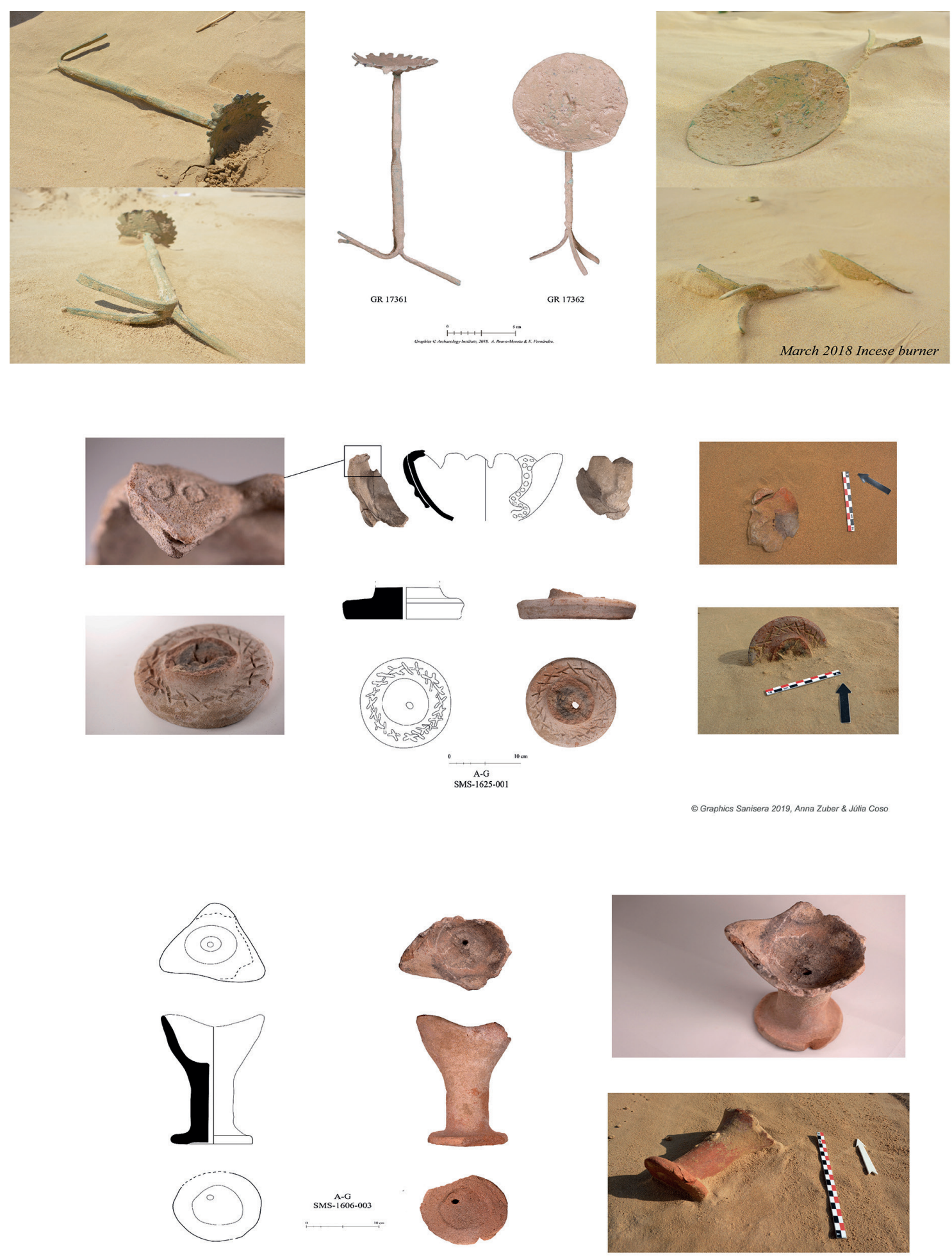

Fig. 15. In Area G, four incense burners were found, both of copper and ceramic, one decorated with a snake appliqué. (C) Edurne Fernández (Sanisera Archaeology Institute). 


\section{Conclusions}

From all the evidences mentioned, is seems that Saruq al-Hadid was not only an important metallurgical centre during the Iron Age II, but also a place where people could gather to trade, perform social celebrations, and thank to a deity - embedded within the snake figuration -, who allowed them to take part in the secrets of fire and metalwork. The rich collection of artefacts that were made, and "offered", at Saruq al-Hadid, shows a society with skilful mastery of the metallurgical arts, but also its intrinsic intra- and extra-regional connections. The resources required to create such an enterprise in this remote location mirrors a society with embedded connections, thriving through mutual collaboration, and integrated within common rituals and culture.

Nevertheless, is obvious that there are still many unanswered questions about Saruq al-Hadid. It also seems that the more we know, the more complex the questions and answers become. Further research on the material collected and excavations on other Areas of the site should be prioritized. Since the discovery of the charcoal-rich mound located in the Military Area and of objects distributions in Areas located west, it became clear that only by identifying other activity zones we will be able to approach many of the questions remaining. We believe that Saruq al-Hadid has a tremendous potential to answer Iron Age questions of social, economic, politic and environmental scope, which can only be achieved by continued research, collaboration and investment.

An incredible collection of copper weaponry, utilitarian objects and jewellery was recovered at the site, however, major typological and interpretative studies remain to be done. The same happens to the bead jewellery, the collection of stamp seals, and the lithic material. Their assessment would favour the interpretation of the site, but also its place within the economic, social, religious and political panorama of SE Arabian during the Iron Age.

Further studies on the modus operandi of the metallurgical production should also be continued. Much still needs to be deciphered, particularly regarding material sources and productive techniques. Several studies on the matter are planned, not only by our team, but also by other teams who collaborate at the site, however funding and schedule availability are not always easy to obtain.

Hydrologic and archaeobotanic studies should also be consider as soon as possible. Questions such us why and how such a place could develop in a remote desert location could be answered by assessing prehistoric environmental conditions of the site.

Finally, we believe the research of Saruq al-Hadid could greatly benefit from further desert survey. There might be similar sites located along the fridges of the Rub al-Khali which could tell us if the metallurgic production was normally restricted to such remote locations, and if these were related to any established economic and/or political networks.

\section{Acknowledgements}

We would like to express our gratitude to everyone from the Sanisera Archaeology Institute that participated in the research held at Saruq al-Hadid. Thank you for the team spirit, resilience against adversities, enjoyment in work, and unmeasurable efforts. Appreciation and recognition has to be highlighted to Anna Zuber, Manuel González, Sofia Baqueiro, Edurne Fernández and Julia Coso for all the illustrations, photos, classification and precise descriptions of the objects presented here, as well as to Marta del Mastro for all the GIS maps that beautifully and efficiently helped us interpreted the data, and to Anne Benoist for her insights and contributions to this paper on pottery interpretation and SE Arabian Iron Age society in general. We would also like to thank all the members of Dubai Municipality for all their help and support overcoming the difficulties of each archaeological season. Without their care and interest, none of the research done by our team could have been possible. 


\section{Bibliographical References:}

Al-Khraysheh, F. \& An-Nashef, K., 2007, Dubai: Civilization and Progress throughout Three Thousand Years. Five Seasons of Joint Archaeological Excavations between the Emirate of Dubai and the Hashemite Kingdom of Jordan at Sarouq al-Hadeed, Dubai: Department of Tourism and Commerce Marketing, Government of Dubai, UAE. In Arabic.

Benoist A., 1999, La céramique de l'Age du Fer en péninsule d'Oman. PhD Thesis, University of Paris I, Paris.

Benoist, A., 2010a, "Authority and Religion in South East Arabia during the Iron Age: a Review of Architecture and Material from Columned Halls and Cultic Sites", in A. Avanzini (ed.) Eastern Arabia in the First Millennium BC, International Conference, Pisa 12th-13th May 2008. Rome: L'Erma di Bretschneider. Arabia Antica 6, pp. 109-141.

Benoist, A., 2010b, "Fouilles à Masafi-3 en 2009 (Emirat de Fujeirah, E.A.U.): Premières observations à propôs d'un espace cultuel de l'Age du Fer nouvellement découvert en Arabie Orientale", Proceedings of the Seminar for Arabian Studies 40, pp. 119-130.

Benoist, A. \& Ali Hassan, S., 2010, "Inventory of objects from a second Millennium Burial in Dadna (Emirate of Fujairah)", in L. Weeks, (ed.) Death and burials in Arabia and beyond. BAR International Series 2107, ArchaeoPress, Oxford, pp. 85-99.

Benoist, A., Bernard, V., Charbonnier, J., Goy, J., Hamel, A. \& Sagory, T., 2012a, "Une occupation de l'âge du fer à Masafi", Arabian Humanities 17, pp. 1-21.

Benoist, A., Bernard, V., Le Carlier, C., Hamel, A., Mmashkour, M., Pillaut, S., Ploquin, A., Rougeulle, A., Saint-Genez, F., Saliège, J.F., Schiettecatte, J., Skorupka, M. \& Zazzo, A., 2012b, La vallée de Bithnah au cours de l'âge du fer, British Foundation for the Study of Arabia Monographs 14, BAR S2510. Oxford: Archaeopress.

Benoist, A., Carlier, C., Goy, J., Degli Esposti, M., Armbruster, B. \& Attaelmanan, G., 2015, "Snake, copper and water in south-eastern Arabian religion during the Iron Age: the Bithnah and Masafi evidence", in M. Arbach \& J. Schiettecatte, (eds.) Pre-Islamic South Arabia and its Neighbours: New Developments of Research, Proceedings of the 17th Rencontres Sabeennes held in Paris, 6-8 June 2013, British Foundation for the Study of Arabia Monographs No.16, BAR International Series 2740, pp. 21-36.

Benoist, A. \& Méry, S., 2012, "Initial Results from the program of petrographic analysis of Iron Age pottery from the United Arab Emirates", Arabian Archaeology and Epigraphy 22, 70-91.

Boucharlat, R. \& Lombard, P., 1985, "The oasis of al-Ain in the Iron Age: Excavations at Rumeilah 1981-1983. Survey at Hili 14", AUAE 4, pp. 44-73.

Casana, J., Herrmann, J. T. \& Qandil, H.S., 2009, "Settlement history in the Eastern Rub alKhali: Preliminary Report of the Dubai Desert Survey (2006-2007)", Arabian Archaeology and Epigraphy 20, pp. 30-45.

Contreras, F., Carcacer, N., Thomas, J., Koljic, D., Murray, M., Bukhash, R.M., Al Abbar, S.O., Boraik, M. \& Zein, H.M., 2016, "Al-Ashoosh: a third-millennium BC desert settlement in the United Arab Emirates", Antiquity 90, pp. 1-6.

Contreras, F., Vila, B., Albarracín, P., Bukhash, R.M., Al Abbar, S.O., Karim, M.B.R. \& Zein, H.M., 2017, "Excavations in area 2A at Saruq al-Hadid: Iron Age II evidence of copper production and ceremonial activities", Proceedings of the Seminar for Arabian Studies 47, pp. 57-66. 
Fritz, C.D., 2009, A Regional Ceramic Analysis of Iron Age II Southeastern Arabia, PhD diss., Bryn Mawr College.

Genchi, F., Giardino, C. \& Castelluccia, M., 2013, Explorations at As-Safah. An Early Iron Age metal workshop at the edge of the Rub Al-Khali, Unpublished report, Ministry of Heritage \& Culture of the Sultanate of Oman

Herrmann, J.T., Casana, J. \& Qandil, H.S., 2012, “A sequence of inland desert settlement in the Oman peninsula: 2008-2009 excavations at Saruq al-Hadid, Dubai, UAE”, Arabian Archaeology and Epigraphy 23, pp. 50-69.

Karim, M, 2017, Seals from the Archaeological site of Saruq al Hadid, Urban Heritage and Archaeology Department, Dubai Municipality, (in Arabic).

Kennet, D., 2002, Sassanian and Islamic Pottery from Ras al Khaimah. Classification, Chronology and Analysis of trade in the western Indian Ocean, Oxford Archaeopress Society for Arabian Studies Monographs 1, eBook version.

Magee, P., 1997, "The Iranian Iron Age and the Chronology of Settlement in Southeastern Arabia”, Iranica Antiqua XXXIL, pp. 91-108.

Magee, P., 1998, "New evidence of the appearance of Iron in SE Arabia", Arabian archaeology and Epigraphy 9/1, pp. 112-117.

Magee, P., 2003, "Columned Halls, power and legitimisation in the southeast arabian Iron Age", in Hellyer, P. \& al Aboodi, N. (eds.), Archaeology of the United Arab Emirates. Proceedings of the first international conference on the Archaeology of the U.A.E., London, pp. 181-191.

Magee, P., 2007, "Beyond the Desert and the Sown: Settlement Intensification in Late Prehistoric Southeastern Arabia”, Bulletin of the American Schools of Oriental Research 347, pp. 83-105.

Mouton, M., Benoist, A. \& Cordoba, J., 2011, "The Snake figuration in Iron Age society", Liwa. Journal of the National Center for Documentation \& Research 3, n.5, pp. 3-24

Nashef, K., 2010, "Sārūq al-Hadīd: an industrial complex of the Iron Age II period". In: A. Avanzini, (ed.), Eastern Arabia in the First Millennium BCA, Rome: L'Erma di Bretschneider. Arabia Antiqua 6, pp. 213-226.

Parker, A.G., Preston, G., Walkington, H. \& Hodson, M.J., 2006, "Developing a Framework of Holocene Climatic Change and Landscape Archaeology for the Lower Gulf Region, Southeastern Arabia", Arabian Archaeology and Epigraphy 16, pp. 125-130.

Potts, D.T., 1991, Further Excavations at Tell Abraq, Munksgaard.

Potts, D.T., 1992, The Arabian Gulf in Antiquity. From Prehistory to the Fall of the Achaemenid Empire. Volume I. Oxford.

Potts, D.T., 2001, "Before the Emirates: An Archaeological and Historical Account of Developments in the Region c. 5000 BC to 676 AD", in E. Ghareeb \& I. Al-Abed (eds), Perspectives on the United Arab Emirates, London, pp. 28-69.

Potts, D.T., 2012, In the Land of the Emirates. The Archaeology and History of the UAE, Abu Dhabi.

Qandil, H.S., 2005, "Survey and Excavations at Saruq al-Hadeed 2002-2003". In: Hellyer, P. \& Ziolkowski, M.C. (ed.), Emirates Heritage. Vol. 1. Proceedings of the first Annual Symposium on Recent Palaeontological and Archaeological Discoveries in the Emirates, Al Ain 2003. Al Ain, pp. $120-138$. 
Soriano, I., Perea, A., Escanilla, N., Contreras, F., Al Ali, Y.Y., Karim, M.B.R. \& Zein, H., 2018, "Goldwork technology at the Arabian Peninsula. First data from Saruq al Hadid Iron Age site (Dubai, United Arab Emirates), Journal of Archaeological Science: Reports 22, pp. 1-10.

Taha, M., 2009, The discovery of the Iron Age in the United Arab Emirates, Abu Dhabi.

Valente, T., Contreras, F., Mahmud, A., Al Ali, Y.Y., Karim, M.B.R., 2019, “Anthropomorphic figurines from Area 2A of Saruq al-Hadid, Dubai, UAE", Proceedings of the Seminar for Arabian Studies 49, pp. 283-393.

Weeks, L., 2003, Early Metallurgy of the Persian Gulf. Technology, Trade, and the Bronze Age World, Boston and Leiden.

Weeks, L., Cable, C., Franke, K., Newton, C., Karacic, S., Roberts, J., Stepanov, I., David-Cuny, H., Price, D., Bukhash, R.M., Radwan, M.B. \& Zein, H, 2017, "Recent Archaeological Research at Saruq al-Hadid, Dubai, UAE”, Arabian Archaeology and Epigraphy 28, pp. 31-60.

Weeks, L., Cable, C..M, Franke, K.A., Karacic, S., Newton, C., Roberts, J., Stepanov, I., McRae, I.K., Moore, M.W., David-Cuny, H., Al Ali, Y.Y., Boraik, M. \& Zein, H.M., 2018, "Saruq al-Hadid: a persistent temporary place in late prehistoric, Arabia.World Archaeology. doi: 10.1080/00438243.2018.1491324.

Weeks, L., Cable, C., Karacic, S., Franke, K., Price, D., Newton, C., Roberts, J., Al Ali, Y.Y., Boraik, M. \& Zein, M., 2019, "Dating persistent short-term human activity in a complex depositional environment: Late Prehistoric Occupation at Saruq al-Hadid, Dubai", Radiocarbon 61, pp. 10411075 .

Ziolkowski, M.C., 2001, "The Soft Stone Vessels from Sharm, Fujairah, United Arab Emirates, Arabian Archaeology and Epigraphy 12, pp. 10-86. 